\title{
The Response of the Northwest Atlantic Ocean to Climate Change ${ }^{\mathscr{O}}$
}

\author{
Michael A. AleXANDER \\ NOAA/Earth System Research Laboratory, Boulder, Colorado \\ SANG-IK SHIN AND JAMES D. SCOTT \\ NOAA/Earth System Research Laboratory, and Cooperative Institute for Research in Environmental Sciences, \\ University of Colorado Boulder, Boulder, Colorado \\ ENRIQUE CURCHITSER \\ Department of Environmental Sciences, Rutgers, The State University of New Jersey, New Brunswick, New Jersey \\ CHARLES STOCK \\ NOAA/Geophysical Fluid Dynamics Laboratory, Princeton, New Jersey
}

(Manuscript received 14 February 2019, in final form 20 September 2019)

\begin{abstract}
ROMS, a high-resolution regional ocean model, was used to study how climate change may affect the northwestern Atlantic Ocean. A control (CTRL) simulation was conducted for the recent past (1976-2005), and simulations with additional forcing at the surface and lateral boundaries, obtained from three different global climate models (GCMs) using the RCP8.5 scenario, were conducted to represent the future (2070-99). The climate change response was obtained from the difference between the CTRL and each of the three future simulations. All three ROMS simulations indicated large increases in sea surface temperatures (SSTs) over most of the domain except off the eastern U.S. seaboard resulting from weakening of the Gulf Stream. There are also substantial intermodel differences in the response, including a southward shift of the Gulf Stream in one simulation and a slight northward shift in the other two, with corresponding changes in eddy activity. The depth of maximum warming varied among the three simulations, resulting in differences in the bottom temperature response in coastal regions, including the Gulf of Maine and the West Florida Shelf. The surface salinity decreased in the northern part of the domain and increased in the south in all three experiments, although the freshening extended much farther south in one ROMS simulation relative to the other two, and also relative to the GCM that provided the large-scale forcing. Thus, while high resolution allows for a better representation of currents and bathymetry, the response to climate change can vary considerably depending on the large-scale forcing.
\end{abstract}

\section{Introduction}

The increase in greenhouse gases over the past century has contributed to the warming of most of the world's oceans, including highly productive coastal regions responsible for the vast majority of global fish

Supplemental information related to this paper is available at the Journals Online website: https://doi.org/10.1175/JCLI-D-190117.s1.

\footnotetext{
Corresponding author: Michael Alexander, michael.alexander@ noaa.gov
}

catch (e.g., Pauly and Zeller 2016). For example, Belkin (2009) found that 61 of the 63 large marine ecosystems (LMEs) that are mainly located in coastal regions exhibited warming from 1982 to 2006, while Lima and Wethey (2012) found that $\sim 3 / 4$ of coastal areas experienced an increase in SST, with an overall rate of $0.25^{\circ} \mathrm{C}(10 \mathrm{yr})^{-1}$, from 1982 to 2010 . While broad warming due to accumulating greenhouse gases is likely to continue, these trends may be significantly exacerbated (or ameliorated) by regional processes such as the retreat of sea ice, changes in finer-scale features, such as fronts and eddies, and the effects of small-scale coastal/ bathymetric features on the response to climate change. 


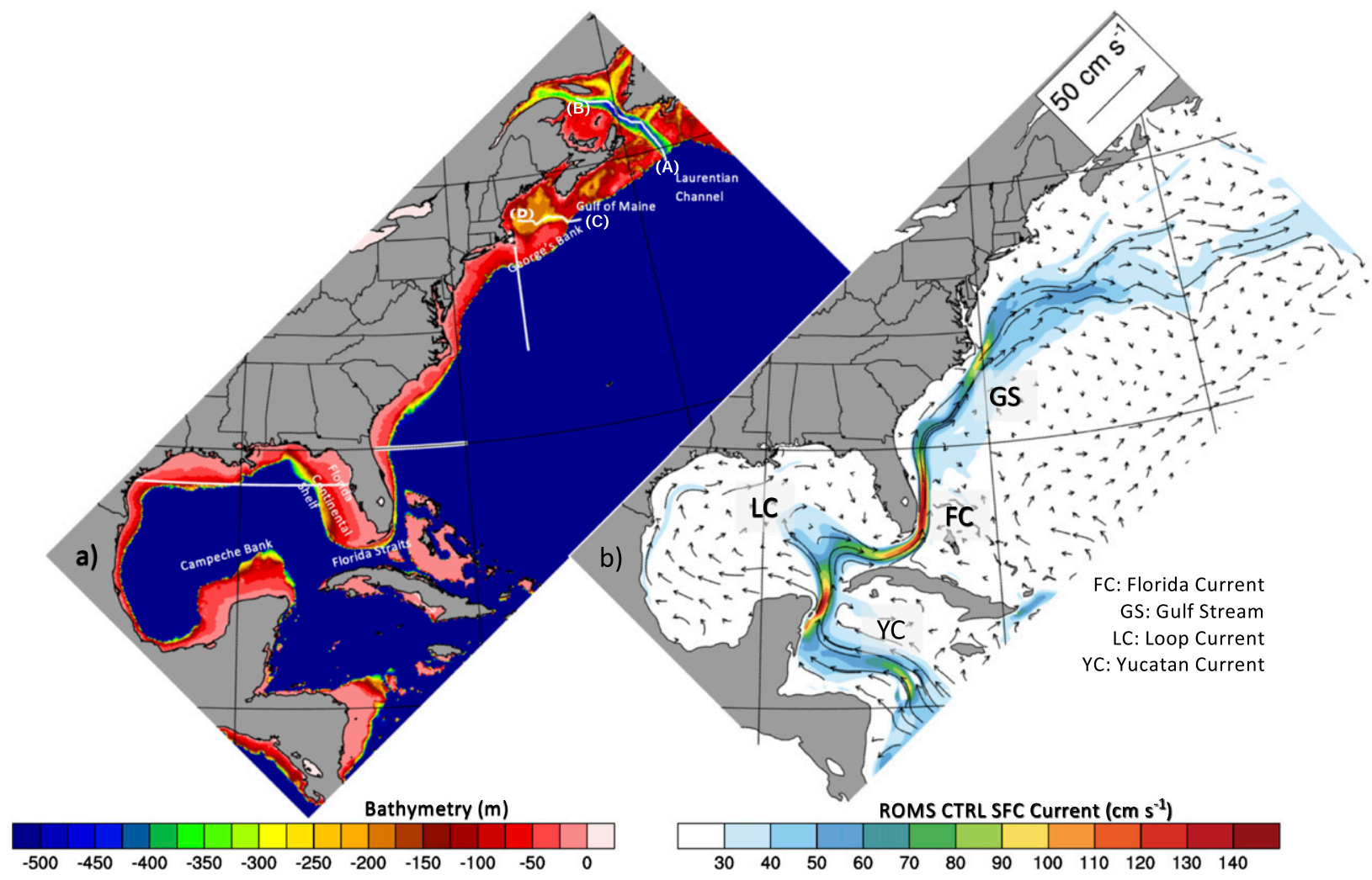

FIG. 1. ROMS domain with (a) bathymetry (shaded, 25-m interval) at 1.85-km resolution. White lines/transects depict the locations of cross sections shown for the Laurentian Channel (Fig. 7), Gulf of Maine (Fig. 8), $28^{\circ} \mathrm{N}$ in the Gulf of Mexico (Fig. 9), 30 ${ }^{\circ} \mathrm{N}$ east of Florida (Fig. 12), and $70^{\circ} \mathrm{W}$ south of Cape Cod (Figs. 14 and 16). (b) Annual mean surface currents (shaded, interval of $10 \mathrm{~cm} \mathrm{~s}^{-1}$; vector scale is given) from the ROMS control (CTRL) experiment.

Given that complex ocean current systems and highly productive marine ecosystems are often located near land, where climate change-induced warming is expected to be more intense, greenhouse gas-induced changes may have an especially pronounced effects in coastal areas. This could well be the case for the U.S. East Coast and Gulf of Mexico, given the proximity of the Labrador Current, Gulf Stream, and Loop Current and complex bathymetric features such as the Laurentian Channel, Gulf of Maine, Georges Bank, and West Florida Shelf (Fig. 1). Climate change will influence not only SST but also temperature, salinity, and currents throughout the water column, which can subsequently impact marine ecosystems. Thus, models and datasets with high spatial resolution may be necessary to fully diagnose and simulate the effects of climate change in the northwest Atlantic and Gulf of Mexico.

Consistent with the potential for regional dynamics to shape large-scale warming patterns, observational analyses indicate a range in SST trends along the east coast of North America. Belkin (2009) found moderate to strong warming for the Scotian Shelf, moderate warming in the Gulf of Mexico, and modest warming on the northeast and southeast U.S. shelf between 1982 and 2006, although the warming was very strong for the northeast United States over the longer period of 1957-2006. Analyses of observations directly adjacent to the coast suggest weak cooling in the southeast and somewhat stronger warming for the northeast U.S. coast (Shearman and Lentz 2010; Lima and Wethey 2012), where Gulf of Maine SST increased by more than $2^{\circ} \mathrm{C}$ between 2004 and 2013, nearly the largest increase over the global ocean during that period (Pershing et al. 2015)

Large changes are also projected for the North Atlantic Ocean in the future. Alexander et al. (2018) found that SSTs increase by approximately $0.3^{\circ}-0.4^{\circ} \mathrm{C}(10 \mathrm{yr})^{-1}$ over the period 1976-2099 for LMEs along the U.S. East Coast with even stronger warming of $0.5^{\circ} \mathrm{C}(10 \mathrm{yr})^{-1}$ on the Scotian Shelf based on simulations using the representative concentration pathway 8.5 (RCP8.5) scenario from phase 5 of the Coupled Model Intercomparison Project (CMIP5) archive. "Polar amplification," with enhanced warming at high latitudes and a reduction in Arctic Sea ice, likely contributes to changes over the Atlantic through both the atmosphere and the ocean 
(e.g., Pedersen et al. 2016; Chen et al. 2014; Coumou et al. 2018; Sun et al. 2018). In general, the models indicate that ocean warming is greatest near the surface, which enhances the static stability, as does the surface freshening of the Atlantic north of $\sim 45^{\circ} \mathrm{N}$ (Capotondi et al. 2012). The enhanced stratification, particularly at high latitudes in the North Atlantic, reduces convection and slows the Atlantic meridional overturning circulation (AMOC; e.g., Cheng et al. 2013; Collins et al. 2013). In turn, changes in AMOC influence temperature and salinity (Drijfhout et al. 2012). In the CMIP5 models, a decrease in AMOC is associated with cooling south of Greenland (warming hole), warming southeast of Nova Scotia, decreased salinity in the subpolar gyre, and increased salinity in the subtropical gyre, especially near the southeast U.S. coast (Cheng et al. 2013). Changes in AMOC have the potential to alter basinwide circulation patterns that impact the physical/ biological ocean response off the east coast of North America.

The resolution of the global climate models (GCMs) used in CMIP5 is relatively coarse, with an ocean resolution on the order of $100 \mathrm{~km}$, which does not resolve finescale topographic features and may not adequately represent aspects of the ocean dynamics. For example, these models do not resolve ocean eddies and simulate the separation of the Gulf Stream from the coast north of its observed location at Cape Hatteras (e.g., Bryan et al. 2007), which can influence the response to increasing greenhouse gases (Winton et al. 2014). Saba et al. (2016) investigated the response of GCMs developed at the NOAA/Geophysical Fluid Dynamics Laboratory (GFDL) with varying atmosphere and ocean resolutions to a doubling of $\mathrm{CO}_{2}$ (after an increase of $1 \%$ per year). They found that the response to climate change varied with resolution, especially along the northeast U.S. coast, where the increase in temperature was much stronger in the simulation with the finest resolution: $50 \mathrm{~km}$ in the atmosphere and $10 \mathrm{~km}$ in the ocean. At this resolution, the SST warming off portions of the East Coast exceeded $5^{\circ} \mathrm{C}, \sim 2.5$ times the increase in the global mean and double that of the coarseresolution GCM. The warming was especially strong in the Gulf of Maine, where very warm water from the Atlantic entered the gulf at depth through the Northeast Channel, which was only resolved in the highest resolution simulation. The surface salinity increased along most of the U.S. East Coast shelf, with strong increases in bottom salinity along the North and South Carolina coast and into the Gulf of Maine and Scotian Shelf via deep channels. Saba et al. (2016) attributed these changes in temperature and salinity to a decrease in AMOC and a northward shift of the Gulf Stream.
While the projected changes in the Atlantic temperature, salinity, and currents are generally consistent with those observed to date (e.g., Boyer et al. 2005; Wu et al. 2012; Knutson et al. 2013; Caeser et al. 2018), both the observed and simulated changes could reflect decadal climate variability. In addition, there are large differences between models in their representation of AMOC, other atmospheric and ocean processes, and their response to climate change (e.g., Gregory et al. 2005; Danabasoglu 2008; Cheng et al. 2013; Karspeck et al. 2017). Even small differences in the basin-scale response to climate change could result in large differences in coastal regions. Thus, while the high-resolution GCM study of Saba et al. (2016) is very informative, it is based on a highly idealized $\mathrm{CO}_{2}$ scenario and represents just one potential future for the North Atlantic Ocean. Since high-resolution global models are very computationally intensive, an alternative approach is to dynamically downscale the large-scale changes obtained from the GCM simulations using regional ocean models forced by GCM output along their open-ocean lateral boundaries and at the surface. Usually the GCM forcing is bias corrected, removing the mean difference between the model and observations in the historical period. Dynamically downscaled climate change simulations have been conducted for several regions including the California Current System (Auad et al. 2006; Xiu et al. 2018), the Bering Sea (Hermann et al. 2016), western North Pacific (Liu et al. 2016), Australian boundary currents (Sun et al. 2012), and the Caribbean/Gulf of Mexico (Liu et al. 2012; van Hooidonk et al. 2015; Liu et al. 2015). The regional model studies of the Gulf of Mexico indicate weakening of the Loop Current and associated warm transient eddies, which reduces the amount of anthropogenic warming especially in spring, while surface heating leads to intense warming on the northeastern shelf in summer (Liu et al. 2015). The experiments conducted by Liu et al. $(2012,2015)$, however, used a multi-GCM mean to drive a regional ocean model, and thus retained only the linear component of the climate change forcing and were not able to assess the range of the response.

Shin and Alexander (2020) examined the climate change response of a regional ocean model in the northwest Atlantic including the Gulf of Mexico and off the U.S. East Coast. That simulation was driven by output from the GFDL ESM2M model, a GCM in the CMIP5 archive, and indicated enhanced warming near the coast, including warming at depth in the Gulf of Maine. Here we force the same regional model using fields from three different GCMs, enabling us to generate a range of responses and test their robustness. We also examine a wide range of variables including 
SST, bottom temperature, surface and bottom salinity, static stability, currents, and eddies, over much of the northwest Atlantic, from the western Caribbean Sea to the Gulf of Saint Lawrence. We present the results for December-February (DJF) and June-August (JJA), since the energetics of the Gulf Stream are seasonally dependent (Kang et al. 2016) and the response to climate change can differ between winter and summer (e.g., Alexander et al. 2018). The model and experiment design are described in section 2 , the findings from the regional model are presented in section 3 , and the results are summarized and discussed in section 4 .

\section{Models and methods}

\section{a. Regional ocean model}

We used the Regional Ocean Modeling System (ROMS; Shchepetkin and McWilliams 2003, 2005) to investigate the effects of climate change on the northwest Atlantic. ROMS is a terrain-following primitive equation model with a free surface using incompressible and hydrostatic approximations. The version used here, configured by Kang and Curchitser (2013), has a horizontal grid spacing of $7 \mathrm{~km}$ and 40 vertical sigma levels with higher resolution near the surface. The domain extends along the east coast of North America from approximately $10^{\circ}$ to $52^{\circ} \mathrm{N}$, covering the western Caribbean, Gulf of Mexico, and the western North Atlantic from Florida to Newfoundland. It includes the Loop Current, Florida Current, Gulf Stream, and the southern portion of the Labrador Current (Fig. 1).

The initial and oceanic boundary forcing for the control (CTRL) ROMS simulation is based on 5-day averages from the Simple Ocean Data Assimilation (SODA, v2.1.6, archived fields are on a $0.5^{\circ}$ latitudelongitude grid with 40 vertical levels; Carton and Giese 2008), 6-hourly surface forcing from the Coordinated Ocean-Ice Reference Experiments (CORE, v2; $\sim 1.9^{\circ}$ latitude-longitude resolution; Large and Yeager 2009) and daily freshwater flux from rivers from the continental discharge database (Dai et al. 2009). The initial conditions and forcing are bilinearly interpolated to the ROMS horizontal grid and linearly interpolated with depth (within the "Pyroms" package), with radiational conditions for flow out of the domain and nudging of temperature, salinity and in-flowing currents as a function of depth at the boundaries. The CTRL simulation is performed using the observed forcing over a 48-yr period: 1958-2005. This ROMS configuration well simulates the mean path of the Gulf Stream and the associated distribution of eddy kinetic energy (Kang and Curchitser 2013, 2015), the circulation in the Gulf of Maine (Shin and Alexander 2020), and temperatures on the continental shelf in the midAtlantic Bight (Chen et al. 2018).

\section{b. Climate change simulations_- "Delta method"}

The large-scale climate change forcing is implemented using the "delta method," in which the difference between mean conditions from a future period and a recent period is added to observations that vary with time during the recent period. Since the recent period's mean climate and high-frequency variability are retained from observations, this method removes the mean bias and retains realistic unforced climate variability over a range of time scales. However, it does not allow for a change in variability in the future, and it assumes that the mean climate state and the projected change are not highly correlated, in other words, that the bias is not strongly dependent on the mean climate state (e.g., Hare et al. 2012). Here, the delta $(\Delta)$ values were obtained by subtracting the mean values during 1976-2005 from those in 2070-99, where the future period is simulated based on RCP8.5, representing the "business as usual" scenario assuming little to no stabilization of greenhouse gas emissions by 2100 . Since a key aspect of this study is to perform a comprehensive analysis of multiple models, which is computationally intensive, we chose to use the RCP8.5 scenario as it has the greatest increase in greenhouse gases in IPCC AR5, and thus should have the largest signal-to-noise ratio.

The $\Delta$ s were computed for each calendar month and then interpolated to daily values, which were then added to the CTRL initial ocean conditions and to the observed forcing during each year of the CTRL simulation. Like the CTRL, the RCP8.5 (CTRL $+\Delta$ forcing) ROMS simulations are $48 \mathrm{yr}$ long. The ROMS response to the inclusion of GCM forcing is obtained from the average of the RCP8.5 - CTRL values over the last $30 \mathrm{yr}$ of the simulation (1976-2005 in the CTRL), allowing the model time (18yr) to spin up to the additional forcing.

An additional benefit of the delta method is that since both the CTRL and the three experiments use the same present-day forcing, they include the same linear portion of any model drift (although changes over time in the CTRL are expected due to observed changes in the forcing). Indeed, local SST trends in the three experiments are substantially reduced after subtracting out the CTRL trend. Trends are of both signs over the domain, nearly compensating each other, indicating nearequilibrium conditions in a basinwide sense (not shown). However, even after subtracting out the trend values from 
TABLE 1. The three GCMs used to compute the delta $(\Delta)$ values, or the mean difference between the periods (2070-99) and (19762005), to incorporate the large-scale climate change forcing. The transient climate response, the change in global and annual mean surface temperature from an experiment in which the $\mathrm{CO}_{2}$ concentration is increased by $1 \% \mathrm{yr}^{-1}$, is calculated using the difference between the start of the experiment and a 20-yr period centered on the time of $\mathrm{CO}_{2}$ doubling (Flato et al. 2013). The AMOC values [Sv (1 Sv $\equiv$ $\left.10^{6} \mathrm{~m}^{3} \mathrm{~s}^{-1}\right)$ ] are given by the maximum overturning streamfunction value in the Atlantic Ocean. The transient climate response and AMOC are indicated as weak, moderate, and strong relative to the large set of CMIP5 models (Flato et al. 2013; Cheng et al. 2013; Collins et al. 2013; Heuzé 2017).

\begin{tabular}{|c|c|c|c|c|c|c|}
\hline Modeling center & Model & $\begin{array}{l}\text { Atmosphere } \\
\text { resolution }\end{array}$ & Ocean resolution & $\begin{array}{l}\text { Transient } \\
\text { climate } \\
\text { response }\end{array}$ & $\begin{array}{l}\text { AMOC strength } \\
1976-2005\end{array}$ & $\begin{array}{l}\triangle \mathrm{AMOC} \\
\text { strength }\end{array}$ \\
\hline $\begin{array}{l}\text { NOAA GFDL } \\
\text { (United States) }\end{array}$ & ESM2M & $\begin{array}{c}2^{\circ} \text { lat } \times 2.5^{\circ} \text { lon; } \\
24 \text { levels }\end{array}$ & $\begin{array}{l}\sim 1^{\circ} \text { lat } \times 1^{\circ} \text { lon; } \\
\text { meridional resolution } \\
\text { increases from } 30^{\circ} \mathrm{N} / \mathrm{S} \\
\text { to } 1 / 3^{\circ} \text { on the equator; } \\
\text { tripolar grid }>65^{\circ} \mathrm{N} ; \\
50 \text { levels }\end{array}$ & $\begin{array}{c}1.3 ; \\
\text { weak }\end{array}$ & $\begin{array}{l}17.9 \mathrm{~Sv} ; \\
\text { moderate }\end{array}$ & $\begin{array}{l}-6.9 \mathrm{~Sv} \\
\text { strong }\end{array}$ \\
\hline IPSL (France) & CM5A-MR & $\begin{array}{l}1.25^{\circ} \text { lat } \times 2.5^{\circ} \text { lon; } \\
39 \text { levels }\end{array}$ & $\begin{array}{l}\sim 2^{\circ} \text { lat } \times 2^{\circ} \text { lon; } \\
\text { meridional resolution } \\
\text { increases to } 1 / 2^{\circ} \text { on the } \\
\text { equator; } 31 \text { levels }\end{array}$ & $\begin{array}{l}2.0 ; \\
\text { moderate }\end{array}$ & $\begin{array}{l}12.2 \\
\text { weak }\end{array}$ & $\begin{array}{l}-3.9 \\
\text { weak }\end{array}$ \\
\hline $\begin{array}{l}\text { Met Office Hadley } \\
\text { Center (United } \\
\text { Kingdom) }\end{array}$ & HadGEM2-CC & $\begin{array}{c}1.875^{\circ} \text { lat } \times 1.25^{\circ} \text { lon; } \\
38 \text { levels }\end{array}$ & $\begin{array}{l}\sim 1^{\circ} \text { lat } \times 1^{\circ} \text { lon } \\
\text { increases from } 30^{\circ} \mathrm{N} / \mathrm{S} \\
\text { to } 1 / 3^{\circ} \text { on the equator; } \\
40 \text { levels }\end{array}$ & $\begin{array}{c}2.5 \\
\text { strong }\end{array}$ & $\begin{array}{c}16.8 ; \\
\text { moderate }\end{array}$ & $\begin{array}{c}-4.4 ; \\
\text { weak to } \\
\text { moderate }\end{array}$ \\
\hline
\end{tabular}

the CTRL, local SST trends still remain in the three experiments, especially in the HadGEM-ROMS simulation, where a strong warming trend occurs off the mid-Atlantic coast (not shown). Thus, the model is still adjusting and/or nonlinear process are creating local changes with time in response to the repeat seasonal cycle forcing.

The surface fields from the GCMs needed to drive ROMS include near surface air temperature and humidity, evaporation minus precipitation (E-P), sea level pressure (SLP), zonal and meridional winds, and the downwelling radiation at the surface. The necessary ocean fields include sea surface height and temperature, salinity, and zonal $(u)$ and meridional $(v)$ currents as a function of depth. Freshwater flux $\Delta \mathrm{s}$ into the ocean from major rivers are applied at the locations identified in the Dai et al. (2009) database.

Choosing climate models to drive regional models is complicated by many factors (e.g., Knutti et al. 2019) including 1) natural variability, which can cause models and observations to differ (e.g., Deser et al. 2014), especially in the Atlantic, which exhibits strong interdecadal variability, 2) "the best" models can differ by which metrics are chosen (e.g., Gleckler et al. 2008; Overland et al. 2011), 3) models that most closely match observations in the present climate may not be the best at simulating long-term trends and thus the response to climate change (Jun et al. 2008), and 4) many models had similar origins and thus are not truly independent (Sanderson et al. 2015). Thus, we do not attempt to use a multimodel mean or to define the best models; rather, we use three different model simulations under the RCP8.5 climate scenario to investigate the sensitivity of their response to strong forcing.

The $\Delta$ values used to initialize and drive ROMS were obtained from GCMs used in the fifth IPCC assessment: the GFDL ESM2M, Institute Pierre Simon Laplace (IPSL) CM5A-MR, and the Hadley Center HadGEM2-CC (HadGEM). These models were chosen in part due to their differences in AMOC in both their climatology and response to anthropogenic forcing and the magnitude of their transient climate response in global surface temperature (Table 1). For example, the transient climate response is weak, moderate, and strong in the GFDL, IPSL, and HadGEM models, respectively. In addition, all three are Earth system models and thus could provide the necessary forcing fields in future downscaling experiments that include ocean biogeochemistry.

\section{Results}

\section{a. Temperature}

The SST response to projected climate change (RCP8.5 - CTRL; shading in Fig. 2) includes warming over nearly the entire domain in both winter (DJF) and summer (JJA) for the three GCM-driven ROMS simulations that are subsequently referred to as GFDL-ROMS, IPSL-ROMS, and HadGEM-ROMS. The warming is lessened in and to the south of the Gulf 


\section{ROMS SST $\left({ }^{\circ} \mathrm{C}\right)$ \\ RCP8.5-CTRL (shaded), CTRL (contour)}

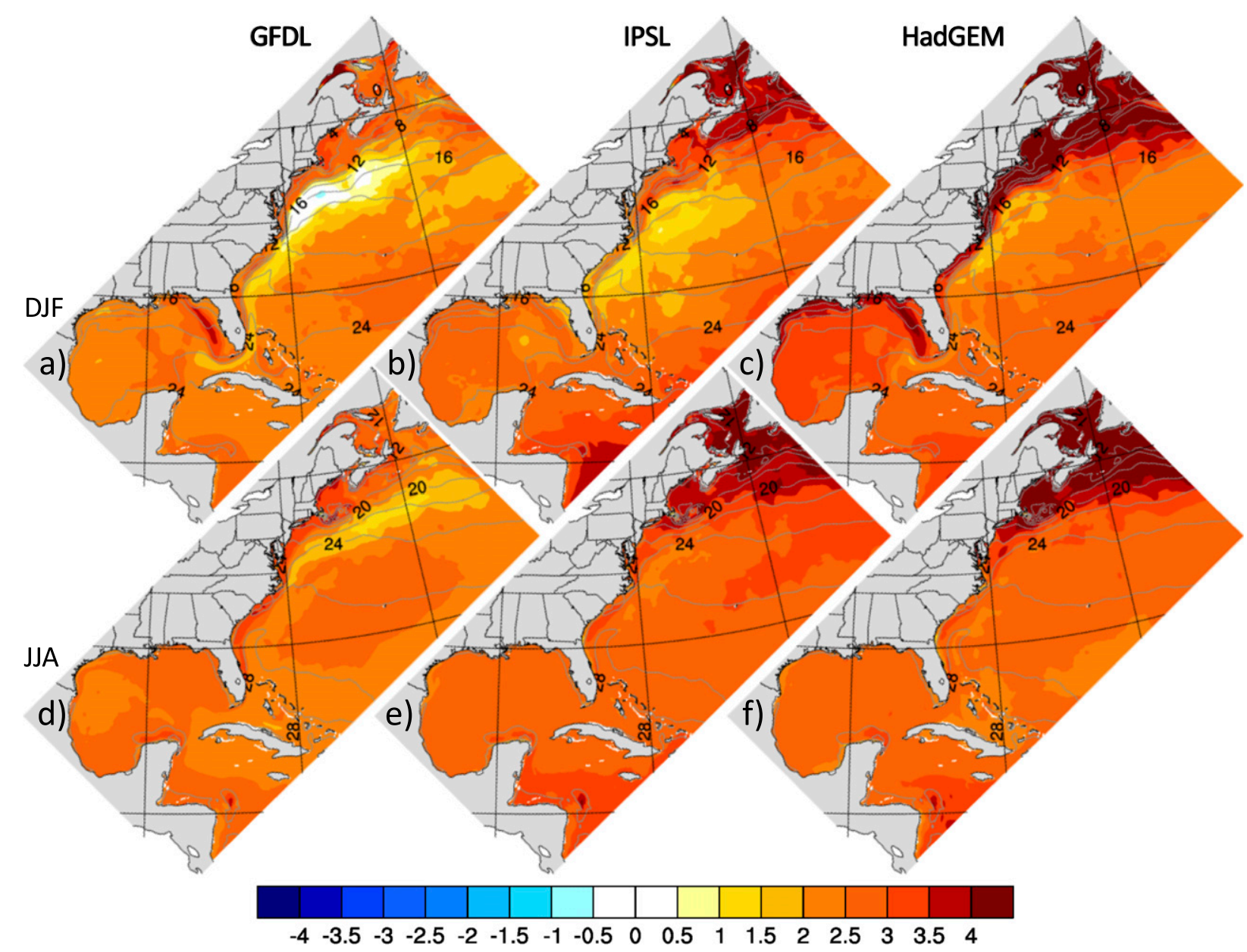

FIG. 2. SST in the CTRL (contours, interval of $2^{\circ} \mathrm{C}$ ) and the SST response to climate change (RCP8.5 - CTRL; shaded, interval of $0.5^{\circ} \mathrm{C}$ ) during (top) DJF and (bottom) JJA in ROMS driven by three GCMs, i.e., (a),(d) GFDL-ROMS, (b),(e) IPSL-ROMS, and (c),(f) HadGEM-ROMS. The surface and boundary conditions for the CTRL are obtained from reanalysis during 1976-2005 (historical period), with additional forcing added to the CTRL that is derived from the mean difference between 2070-99 and 1976-2005 in the three RCP8.5 experiments.

Stream front, as indicated by the region of strong temperature gradients (contours from the CTRL in Fig. 2), during DJF in all three ROMS simulations. This reduced warming is primarily due to changes in the meridional ocean heat transport. As the Gulf Stream slows in the future (i.e., the response opposes the mean current; see section 3e), it transports less heat northward off the southeast U.S. coast (Fig. SM1 in the online supplemental material). From a heat budget perspective, the change in the surface currents times the mean SST gradient is negative, which acts to cool the SSTs (Fig. SM1). While this process occurs in all three simulations, it is especially strong in the GFDL-ROMS experiment. Cooling due to the change in heat transport is weaker in summer than in winter in all three ROMS simulations, mainly due to a relaxing of the meridional SST gradient. Also during summer, a strong shallow mixed layer forms and the surface layer is decoupled from the deeper ocean, which results in stronger thermodynamic air-sea coupling, reducing the effects of the change in heat transport on SST.

There are other notable differences among the three simulations. The IPSL-ROMS and HadGEM-ROMS simulations exhibit very strong warming $\left(>4^{\circ} \mathrm{C}\right)$ in the northwest part of the domain, while the warming in GDFL-ROMS is on the order of $2^{\circ} \mathrm{C}$. Enhanced coastal warming relative to adjacent ocean waters is far more extensive in HadGEM-ROMS than in the other 


\section{GCM AirTemp $\left({ }^{\circ} \mathrm{C}\right)$ RCP8.5-Historical (shaded), Sfc Winds (RCP8.5)}
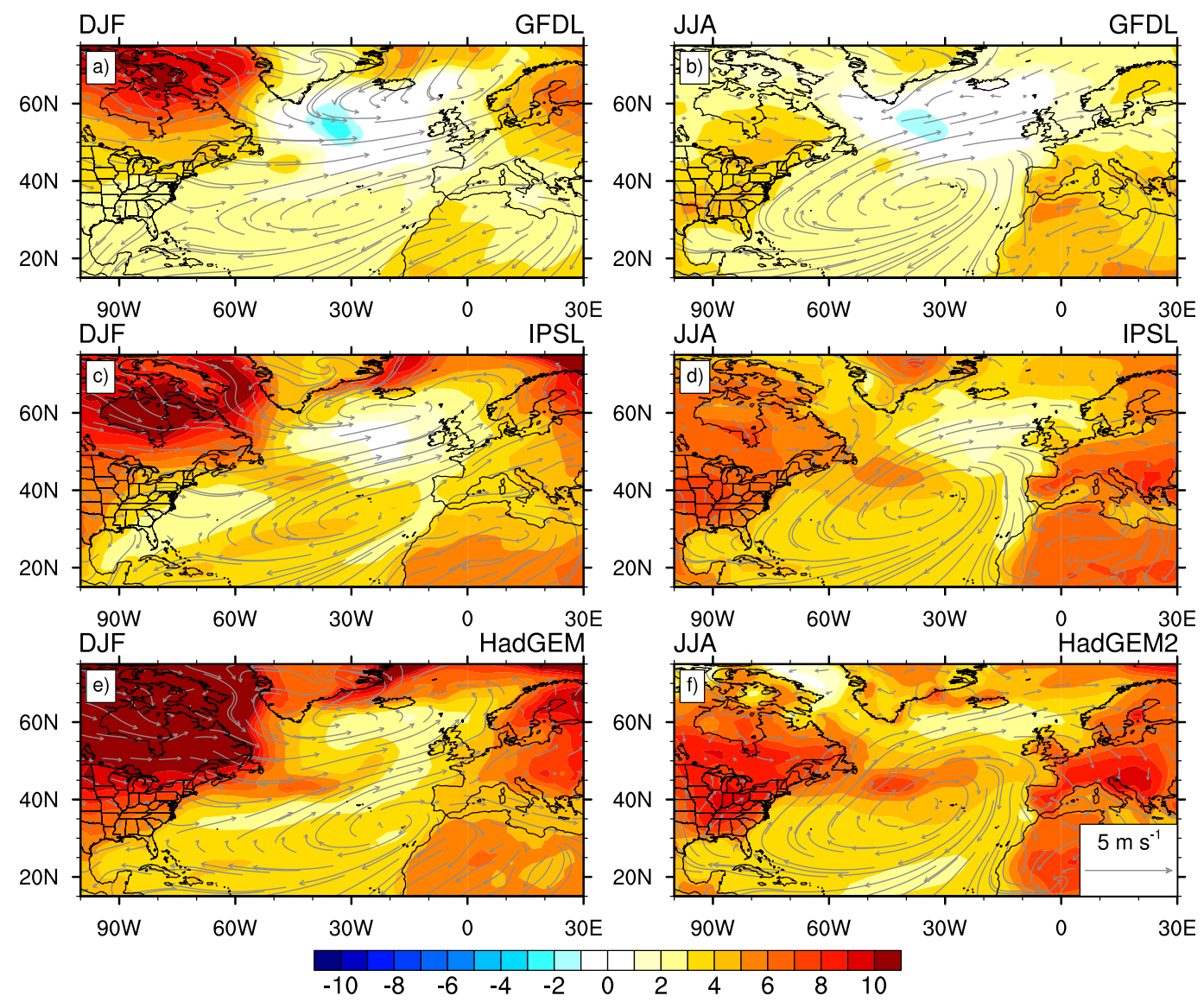

FIG. 3. Surface air temperature change (RCP8.5 - historical period; shaded, $1.0^{\circ} \mathrm{C}$ interval) and the surface winds in the RCP8.5 simulations from 2070 to 2099 (vectors, scale is at bottom right) during DJF and JJA in the (a),(b) GFDL, (c),(d) IPSL, and (e),(f) HadGEM GCMs. This figure highlights how enhanced warming over North America, especially over Canada in winter, could be advected by the winds, warming the coastal ocean in the future.

downscaled simulations during winter, when it extends along the nearly the entire U.S. coast and into Canadian waters. The simulations, especially GFDL-ROMS and HadGEM-ROMS, indicate very strong warming on the outer West Florida Shelf during winter; while Liu et al. (2015) also found enhanced warming in this region, it occurred on the inner shelf in summer.

The broad structure of the three SST responses in ROMS are driven by the basin-scale changes as can be seen by relating the ROMS response to the changes in the corresponding GCM. For example, like the ROMS simulations, the global models indicate reduced warming in the Gulf Stream region and its extension into the North Atlantic (with a corresponding decrease in the currents, section 3e), especially in the GFDL GCM during winter (online supplemental Fig. SM2). The three GCMS also indicate intense warming of the surface air temperature over eastern Canada especially in winter (Fig. 3), partly due to a reduction in sea ice and snow cover in and around Hudson Bay. The mean winds from the west (Fig. 3) can transport the additional heat over the adjacent ocean, where increased air temperature warms the underlying ocean via the surface heat fluxes, especially near the coast. The increase in air temperature over North America corresponds to the overall climate sensitivity of these three GCMs, which is relatively weak, moderate, and strong in the GFDL, IPSL, and HadGEM GCMs (Table 1, Fig. 3), respectively, as are the increases in SST off the coast of the northeast United States and southern Canada in the GCMs (Fig. SM2) and the corresponding ROMS simulations (Fig. 2).

There are also clear differences between the downscaled simulations and the corresponding GCMs that drove them. In the GFDL and IPSL experiments, the downscaled simulation exhibits less warming in the Gulf Stream region when compared with the GCM, while for HadGEM, the ROMS simulation generally exhibits less 


\section{ROMS Bottom Temp $\left({ }^{\circ} \mathrm{C}\right)$ RCP8.5-CTRL (shaded), 200m depth (contour)}
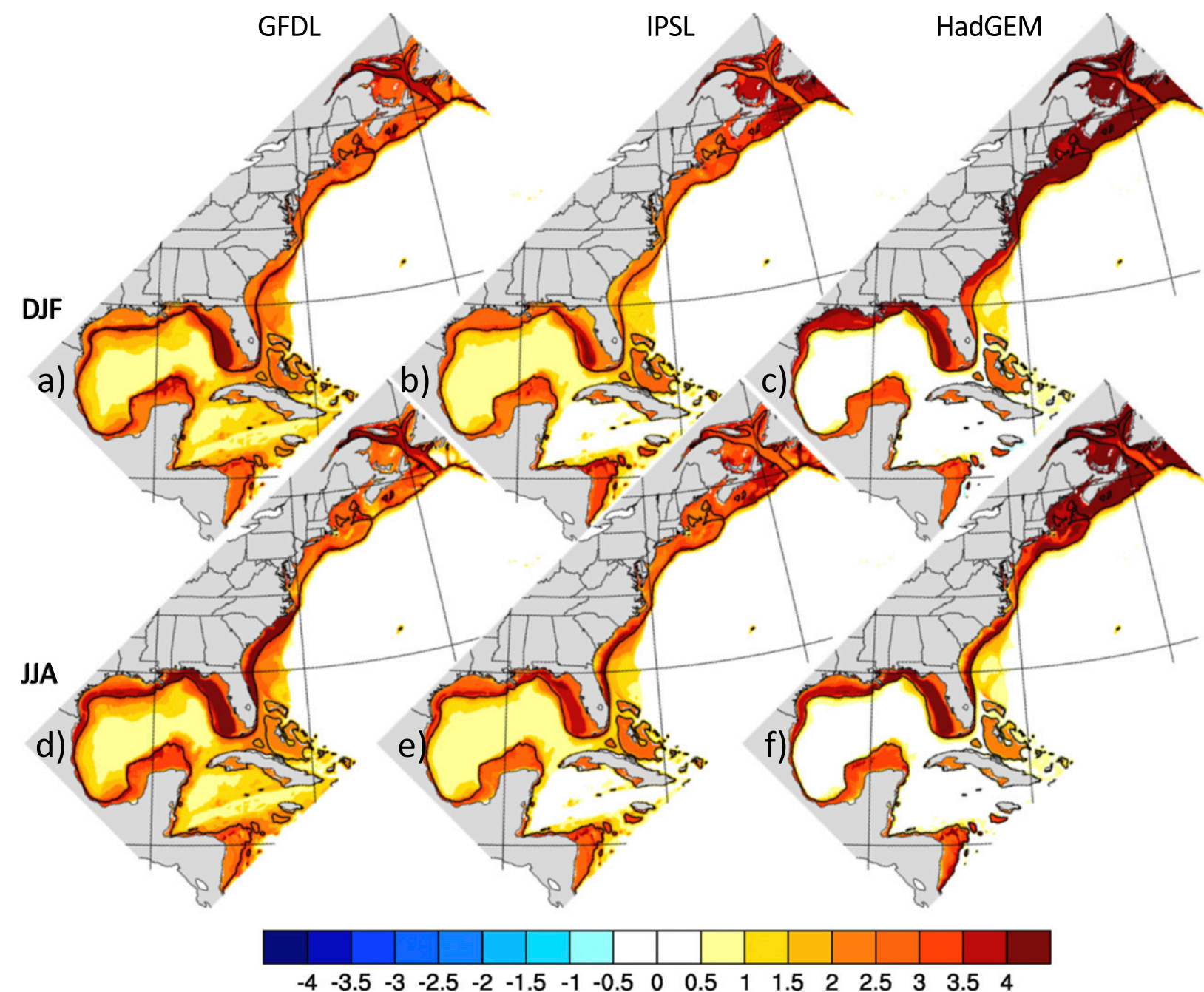

FIG. 4. Bottom temperature response (RCP8.5 - CTRL; shaded, interval of $0.5^{\circ} \mathrm{C}$ ) during (top) DJF and (bottom) JJA in (a),(d) GFDL-ROMS, (b),(e) IPSL-ROMS, and (c),(f) HadGEM-ROMS. The 200-m isobath, representing the shelf break, is indicated by the black curve.

warming over much of the domain except along portions of the eastern seaboard and where the Gulf Stream extends offshore at approximately $35^{\circ} \mathrm{N}$ relative to the driving GCM. Differences between the global and regional SST responses to anthropogenic forcing reached $2^{\circ} \mathrm{C}$ in some locations.

The bottom temperature (BT) response in all three downscaled experiments indicates warming along the entire continental shelf in both DJF and JJA (Fig. 4). They also indicate enhanced warming over portions of maritime Canada, on the shelf in the Gulf of Mexico, and in a narrow band along the shelf break (in the vicinity of the $200 \mathrm{~m}$ isobath) off the southeast U.S. coast in summer. The increase in bottom temperature in coastal regions is often greater than at the surface in all three simulations. For example, the increase in SST during JJA over the West Florida Shelf is on the order of $2.5^{\circ} \mathrm{C}$ but for $\mathrm{BT}$ it exceeds $3.5^{\circ} \mathrm{C}$ in all three ROMS simulation. There are also substantial differences in the detailed BT structure among the three ROMS simulations, which are clearly influenced by both the large-scale forcing and small-scale topographic features (cf. Fig. 4 and online supplemental Fig. SM3). Like SST, the strongest increase in $\mathrm{BT}\left(>4^{\circ} \mathrm{C}\right)$ occurs over a broad region north of Cape Hatteras in HadGEM-ROMS. At regional scales, which are not resolved by the GCMs, 


\section{ROMS SFC Salinity (PSU) \\ RCP8.5-CTRL (shaded)}

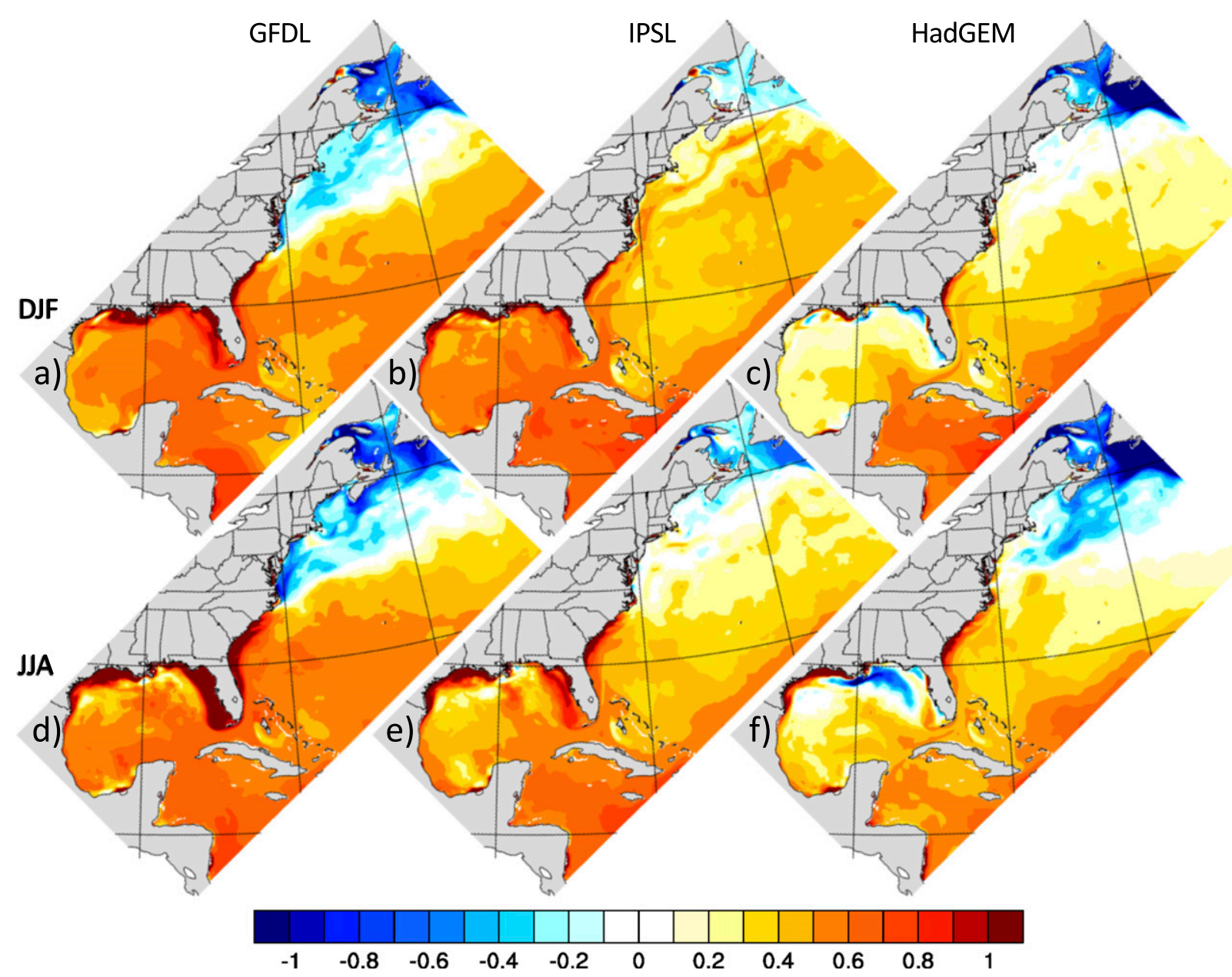

FIG. 5. SSS response (RCP8.5 - CTRL; shaded, interval of 0.1 PSU) during (top) DJF and (bottom) JJA in (a),(d) GFDL-ROMS, (b),(e) IPSL-ROMS, and (c),(f) HadGEM-ROMS. SSS values from the CTRL are not shown, because the contours cover over the response in the northern Gulf of Mexico.

a strong BT response occurs in the Laurentian Channel that extends from the shelf break to the mouth of the Saint Lawrence River in GFDL-ROMS. In contrast, the strongest increase in BT in IPSL-ROMS and HadGEMROMS is not in the bottom of the Channel, but in shallower portions of the Gulf of Saint Lawrence and on the shelf off the coast of Newfoundland and Nova Scotia.

In many locations along the continental shelf, the warming at the bottom is greater than at the surface. If the main source of warming was generated locally through the atmosphere, then the expectation is that the warming would be greatest at the surface and decrease with depth. However, the source for water at depth can differ from those at the surface. Along the northeast coast, much of the source waters originate (are ventilated) in the Labrador Sea/North Atlantic and are transported southward at depth along the shelf (Chen et al. 2018). In all three of our ROMS experiments, the warming due to climate change within or entering the northern part of the domain is especially strong. Changes in temperature and/or flow can alter the heat transport by coastal currents along the shelf, and thus, the change in temperature can be greater at the bottom than at the surface. In addition, the ROMS simulations are much less diffusive than the GCMs and thus are able to resolve coastally trapped currents, leading to enhanced warming along the shelf edge relative to coarse-resolution GCMs (Saba et al. 2016; Shin and Alexander 2020). 


\section{b. Salinity}

The sea surface salinity (SSS) response in ROMS for the three forcing experiments is shown for DJF and JJA in Fig. 5. The SSS values exhibit decreased salinity in the northwest corner of the domain in both summer and winter. Like the ROMS simulations, the large-scale salinity changes in the original GCM simulations indicate a decrease in salinity north of $\sim 40^{\circ} \mathrm{N}$ (online supplemental Fig. SM4), partly due to increased net surface freshwater flux into the ocean: the change in evaporation minus precipitation $[\Delta(\mathrm{E}-\mathrm{P})]$ is generally negative with large amplitude over the center of the subpolar gyre and the southern Labrador Sea (online supplemental Fig. SM5), but more regional E-P changes vary in magnitude and location and by season among the three GCMs. Since the largest response in E-P and the melting of sea ice primarily occur outside of the ROMS domain, the decrease in salinity off the New England and Canadian coast is likely due to advection of fresher water into the region. The salinity increase south of $40^{\circ} \mathrm{N}$ is generally consistent with where $\Delta(\mathrm{E}-\mathrm{P})>0$.

Notable differences in SSS occur along the northeast U.S. coast among the three ROMS simulations and between the individual ROMS simulations and the GCMs that drove them. The southward extent of enhanced freshening along the coast of North America is greatest in GFDL-ROMS, where it extends to North Carolina, while it is primarily confined to Canadian waters in DJF and north of New Jersey in JJA in IPSL-ROMS and HadGEM-ROMS. The freshening along the northeast coast also extends farther south in GFDL-ROMS than in the GFDL GCM itself, while the reverse is true in the IPSL and HADGEM experiments.

The salinity changes in the southern portion of the domain are consistent with enhanced evaporation relative to precipitation in the future climate $[\Delta(\mathrm{E}-\mathrm{P})>0]$ over most of the Atlantic south of $\sim 40^{\circ} \mathrm{N}$ and the Gulf of Mexico in all three GCMs (Fig. SM5). However, there are differences between where $\Delta(\mathrm{E}-\mathrm{P})$ is large and the location and amplitude of the SSS response in the ROMS simulations and the corresponding GCMs in portions of the Gulf of Mexico. This difference is especially notable in the northern Gulf of Mexico in the HadGEM experiment, where $\Delta \mathrm{E}-\mathrm{P}$ is positive and the SSS slightly increases in the GCM but decreases in HadGEM-ROMS. Freshwater entering the Gulf of Mexico from the Mississippi River is greatly enhanced in the HadGEM GCM (online supplemental Fig. SM6) resulting in SSS decreases in the future in HadGEM-ROMS simulations especially in JJA (Fig. 5). Higher vertical and horizontal resolution in conjunction with reduced diffusion coefficients in ROMS relative to the coarse GCMs can act to maintain finescale features, such as river plumes. While the SSS generally increases in the other two ROMS simulations in the Gulf of Mexico, the change is smaller in some northern portions of the basin in JJA, where changes in currents and stratification may also play a role in the detailed pattern of the response.

The response to climate change in the bottom salinity in the three ROMS simulations is shown during DJF and JJA in Fig. 6 (and in online supplemental Fig. SM7 for the GCMs). They have the same general structure as those at the surface over most of the domain, although the magnitude and extent of the changes tend to be smaller at the bottom. However, the response is very different in the Laurentian Channel where the water becomes saltier on the bottom while it is freshening at the surface. The apparent change in the salinity with depth is readily apparent in GFDL-ROMS, where the bottom salinity increases in the Laurentian Channel (depth $>200 \mathrm{~m}$ ) but decreases nearly everywhere else north of Nova Scotia.

\section{c. Cross sections}

The structure of the vertical temperature and salinity changes in the three ROMS integrations is explored further using cross sections in the vicinity of the Laurentian Channel/Gulf of Saint Lawrence, Northeast Channel/Gulf of Maine, and across the northern Gulf of Mexico (see Fig. 1a). Note that the first two sections follow the maximum depth in their respective channels and therefore they do not follow a fixed latitude or longitude. Since the cross sections are qualitatively similar in DJF and JJA, we present the annual mean values for the CTRL (contours) and the RCP8.5CTRL (shading).

In the Gulf of Saint Lawrence, there is a temperature minimum at $\sim 40-\mathrm{m}$ depth and a vertical front near the Atlantic-gulf boundary at $\sim 45^{\circ} \mathrm{N}$ in the 30 -yr climatology from the CTRL simulation (Fig. 7, top panels). While warming occurs throughout the Laurentian Channel, the temperature departures are largest at depth in GFDLROMS (Fig. 7a), while the maximum departures extend from near the surface to about $250 \mathrm{~m}$ in the other two simulations (Figs. 7b,c). The maximum downscaled warming exceeds $3.5^{\circ} \mathrm{C}$ in the GFDL and IPSL, and $5^{\circ} \mathrm{C}$ in HadGEM. All three ROMS simulations indicate freshening of the surface layer, extending to approximately 100-, 75-, and 50-m depth in the GFDL, HadGEM, and IPSL experiments, respectively, but the magnitude of the response is substantially smaller in IPSL-ROMS (Fig. 7, bottom). All three simulations also have an increase in salinity at depth in the Gulf of Saint Lawrence, which slopes downward from the southeast to the northwest. 
ROMS Bottom Salinity (PSU) RCP8.5-CTRL (shaded), 200m depth (contour)

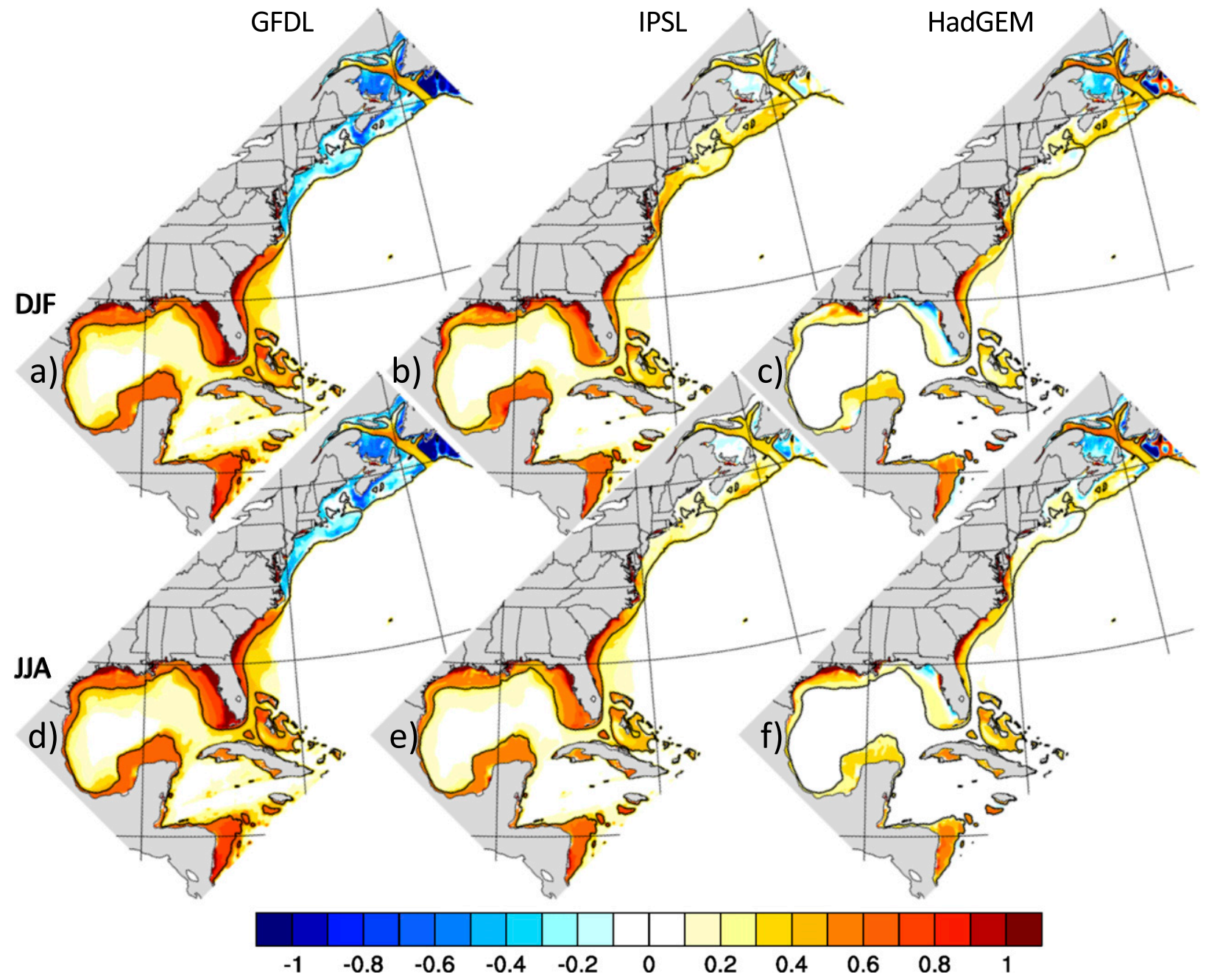

FIG. 6. Bottom salinity response (RCP8.5 - CTRL; shaded, interval of 0.1 PSU) during (top) DJF and (bottom) JJA in (a),(d) GFDL-ROMS, (b),(e) IPSL-ROMS, and (c),(f) HadGEM-ROMS. The 200-m isobath is indicated by the black curve.

The Gulf of Maine section (Fig. 8) includes the Northeast Channel $\left(66^{\circ} \mathrm{W}\right)$, Georges basin $\left(67^{\circ} \mathrm{W}\right)$, and Wilkinson basin $\left(69.5^{\circ} \mathrm{W}\right)$. In the CTRL, there is a strong vertical thermohaline front near the entrance to the Gulf of Maine around $\sim 65.5^{\circ} \mathrm{W}$ with colder and fresher water in the gulf relative to the Atlantic. The strongest warming in GFDL-ROMS is located at depths below $\sim 130 \mathrm{~m}$ in the open ocean (east of $65.5^{\circ} \mathrm{W}$ ), which extends into Georges basin through the Northeast Channel (Fig. 8a; also see Shin and Alexander 2020). In the other two simulations (Figs. 8b,c), the warming occurs higher in the water column, where the temperature departures exceed $5^{\circ} \mathrm{C}$ in HadGEM-ROMS at $\sim 60-\mathrm{m}$ depth at $\sim 67.5^{\circ} \mathrm{W}$. While salinity is enhanced in all three simulations in the Atlantic, the overall response strongly differs between them (Fig. 8, bottom panels). The most notable difference occurs in the surface layer in the Gulf of Maine, where GFDL-ROMS exhibits freshening while the salinity increases in IPSL-ROMS and to a lesser degree in HadGEM-ROMS. In the open ocean, the salinity increases by more than 0.4 practical salinity units (PSU) at depths greater than $\sim 150 \mathrm{~m}$ in GFDL-ROMS, while the changes are slightly smaller and occur higher in the water column in the two other simulations. Only a small amount of the saltier water extends into the Gulf of Maine, likely advected through the Northeast Channel in the GFDL-ROMS, resulting in slightly saltier water below $\sim 200 \mathrm{~m}$ in 
ROMS Laurentian Channel X-section Annual Mean

RCP8.5-CTRL (shaded), CTRL (contour)

$\operatorname{TEMP}\left({ }^{\circ} \mathrm{C}\right)$
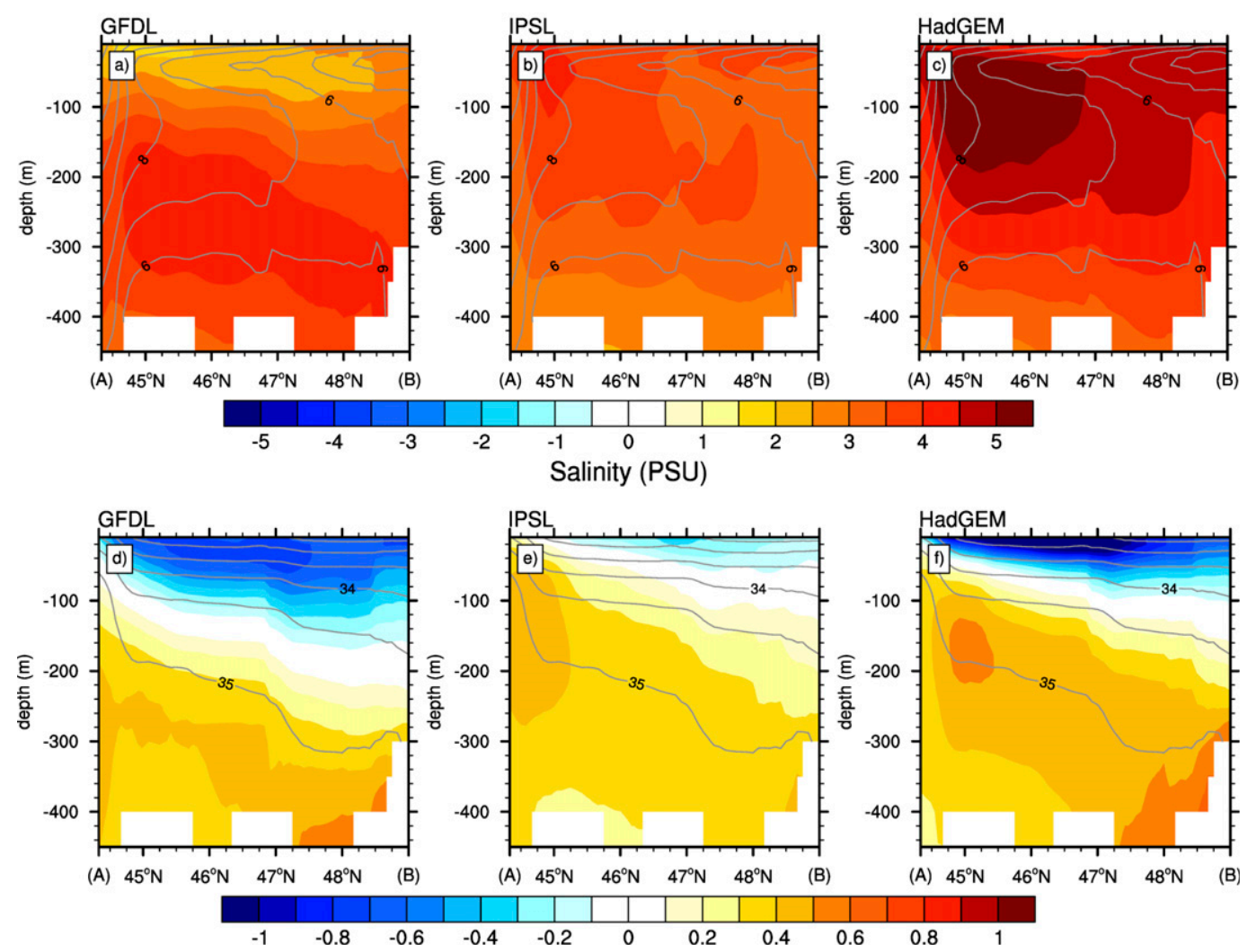

FIG. 7. Cross section of the annual mean (top) temperature and (bottom) salinity along the Laurentian Channel in ROMS. Shown are the temperature from CTRL (contours, interval of $1.0^{\circ} \mathrm{C}$ ) and the response (shaded, interval of $0.5^{\circ} \mathrm{C}$ ) and salinity from the CTRL (contours, interval of $0.5 \mathrm{PSU}$ ) and the response (shaded, interval of $0.1 \mathrm{PSU}$ ) in (a),(d) GFDL-ROMS, (b),(e) IPSL-ROMS, and (c),(f) HadGEM -ROMS. Note that the section is along the bottom of the channel (not a straight line) and extends from the southeast to northwest, from (A) to (B) in Fig. 1.

Georges basin. In IPSL-ROMS, a layer with enhanced salinity penetrates eastward over the entire Gulf of Maine, with a maximum at $\sim 50 \mathrm{~m}$ within the climatological halocline but also with salty water penetrating to the bottom of Georges basin. HadGEM-ROMS is somewhere between the two other experiments, where the increase in salinity also slopes downward into Georges basin, with a weak response above $50 \mathrm{~m}$.

The temperature and salinity changes differ between the surface and the bottom in the northern Gulf of Mexico (sections $3 \mathrm{a}$ and $3 \mathrm{~b}$ ), indicating vertical structure in the response to climate change; thus, we present a zonal section along $28^{\circ} \mathrm{N}$ between the central coasts of Florida and Texas (Fig. 9). The CTRL exhibits a steady decrease in temperature with depth with a maximum gradient from around 40 to $150 \mathrm{~m}$, where the thermocline is stronger and shallower near the coasts. The salinity in the CTRL exhibits much less vertical structure but has a broad maximum over approximately $85^{\circ}-93^{\circ} \mathrm{W}$, with much fresher water near the coasts. In all three ROMS simulations, the temperature change is positive over the full width and depth of the Gulf of Mexico and is larger at depths between approximately 40 and $150 \mathrm{~m}$ than at the surface (Fig. 9 top panels), though the warming is slightly greater and most extensive in GFDL-ROMS. The response is enhanced where the thermocline intersects the West Florida Shelf at $\sim 85^{\circ} \mathrm{W}$, especially in GFDL-ROMS and HadGEMROMS, where it reaches $5^{\circ} \mathrm{C}$, in line with the strong increase in bottom temperature on the west Florida slope (Fig. 4). The respective increases in salinity are relatively strong, moderate and weak in the downscaled GFDL, IPSL, and HadGEM simulations, respectively (Fig. 9, bottom panels). The changes are largest near the Florida coast in GFDL-ROMS and HadGEM-ROMS and near the Texas coast in the shallow climatological 
ROMS Gulf of Maine X-section Annual Mean

RCP8.5-CTRL (shaded), CTRL (contour)

$\operatorname{TEMP}\left({ }^{\circ} \mathrm{C}\right)$
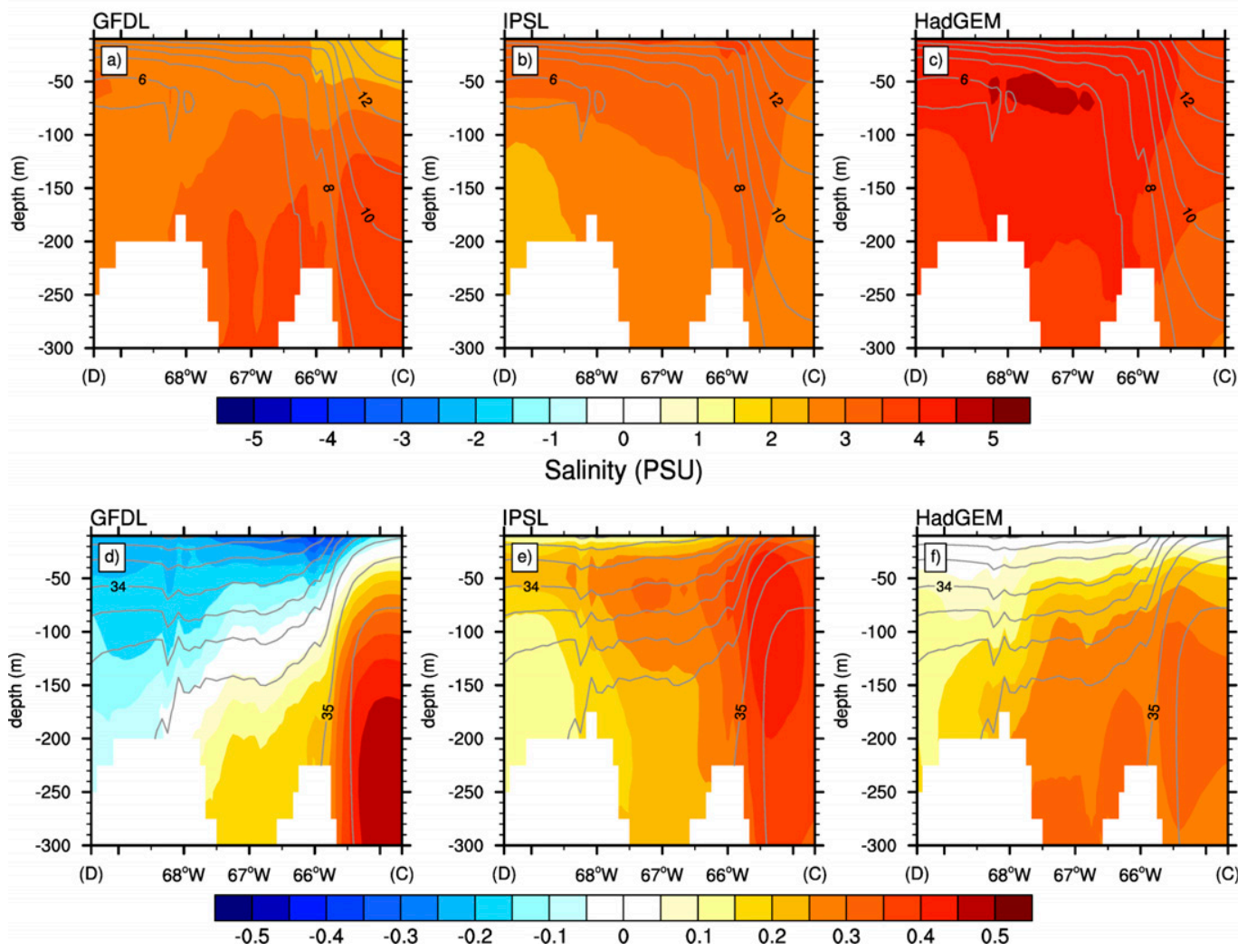

FIG. 8. Cross section of the annual mean (top) temperature and (bottom) salinity into the Gulf of Maine in ROMS. Shown are the temperature from CTRL (contours, interval $1.0^{\circ} \mathrm{C}$ ) and the response (shaded, interval of $0.5^{\circ} \mathrm{C}$ ) and salinity from the CTRL (contours, interval of $0.25 \mathrm{PSU}$ ) and the response (shaded, interval of 0.05 PSU) in (a),(d) GFDL-ROMS, (b),(e) IPSL-ROMS, and (c),(f) HadGEM-ROMS. Note that the section is in the deepest part of the Gulf of Maine (not a straight line) and extends from east to west, from (C) to (D) in Fig. 1.

halocline in all three ROMS integrations. The salinity responses are also enhanced across the entire basin between approximately 40- and 100-m depth in IPSL-ROMS and HadGEM-ROMS; there is a slight increase at approximately 120-m depth in GFDL-ROMS, but it does not extend across the basin.

\section{d. Density}

The depth-dependent changes in temperature and salinity alter the density profile and thus stratification. Stratification, as indicated by the density difference between 100-m depth and the surface, is positive for stable stratification. The changes in stratification are shown for the three ROMS simulations during DJF and JJA in Fig. 10; the separate contributions of temperature and salinity to the annual mean density at the surface, $100 \mathrm{~m}$, and the stratification are shown in online supplemental Fig. SM8. With intensified surface warming in the future most of the open-ocean areas of the North
Atlantic in all three ROMS simulations display an increase in stratification particularly in summer, consistent with Capotondi et al. (2012) and Alexander et al. (2018). The change in the vertical structure of salinity enhances the stratification in the northern part of the domain in all three ROMS simulations, and is especially strong along the northern edge of the Gulf Stream and in the Laurentian Channel in the GFDL and HadGEM models (Fig. SM8). The change in stability is also more complex than just a surface intensified warming in the Gulf Stream region and in the Gulf of Mexico. There is a decrease in stratification in the Gulf Stream near the coast and a near-neutral response as it leaves the coast near Cape Hatteras and extends into the Atlantic (where it is a minimum in the CTRL) during winter. Off the southeast U.S. coast, the weakening of the Gulf Stream is greater at the surface than at depth (discussed in the following section) and there is intensified warming adjacent to the shelf break, both of which may enhance 
ROMS Gulf of Mexico $\left(28^{\circ} \mathrm{N}\right) \mathrm{X}$-section Annual Mean

RCP8.5-CTRL (shaded), CTRL (contour)

TEMP $\left({ }^{\circ} \mathrm{C}\right)$
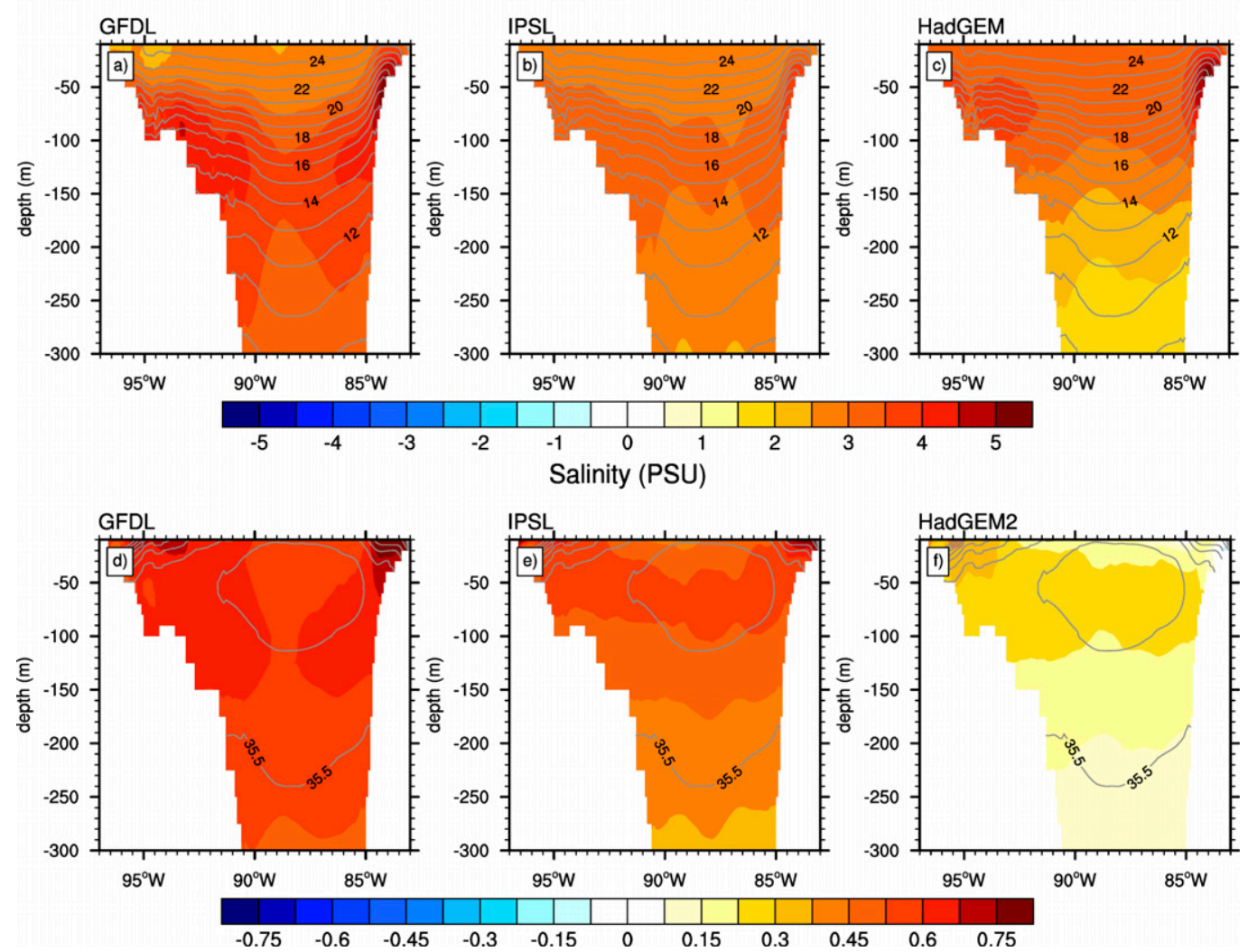

FIG. 9. Cross section of the annual mean (top) temperature and (bottom) salinity along $28^{\circ} \mathrm{N}$ in the northern Gulf of Mexico in ROMS. Shown are the temperature from CTRL (contours, interval of $1.0^{\circ} \mathrm{C}$ ) and the response (shaded, interval of $0.5^{\circ} \mathrm{C}$ ) and salinity from the CTRL (contours, interval of $0.5 \mathrm{PSU}$ ) and the response (shaded, interval of 0.075 PSU) in (a),(d) GFDL-ROMS, (b),(e) IPSL-ROMS, and (c),(f) HadGEM-ROMS.

warming at depth relative to the surface. The stratification actually decreases over nearly all of the Gulf of Mexico in GFDL-ROMS and IPSL-ROMS and in the center of the gulf in HadGEM-ROMS during DJF. In the Gulf of Mexico, warming at 100-m depth, which is within the upper thermocline (Fig. 9), is greater than at the surface, which reduces the stratification in the downscaled simulations (Fig. SM8; the stratification and its decomposition in the three GCMs are shown in online supplemental Figs. SM9 and SM10). The stratification changes vary among the three ROMS simulations over the Gulf of Mexico during JJA (Fig. 10), but all three exhibit decreased stratification in the eastcentral part of the basin $\left(\sim 25^{\circ} \mathrm{N}, 87^{\circ} \mathrm{W}\right)$.

\section{e. Currents}

A clear result in all three ROMS simulations is the weakening of the western boundary current system over the entire domain including the Yucatan, Loop, and
Florida Currents and the Gulf Stream in both winter and summer (Fig. 11). The three forcing GCMs also show a weakening of the western boundary current system in the western North Atlantic, although the reduction in current strength in the IPSL GCM (online supplemental Fig. SM11) is smaller than in IPSL-ROMS. The weakening of the currents is especially pronounced in the Gulf Stream, whose speed decreases by more than $25 \%$ in the three ROMS simulations relative to the CTRL, as indicated by a cross section of the meridional velocity at $30^{\circ} \mathrm{N}$ (Fig. 12). A more detailed map of the annual mean surface currents off the northeast U.S. coast for the CTRL and the response to climate change in three ROMS experiments are shown in Fig. 13. The response in the GFDL-ROMS simulation opposes the mean Gulf Stream flow in the center and northern part of the current with a weak enhancement on its southern flank. This is highlighted in a meridional cross section of the zonal current at $70^{\circ} \mathrm{W}$ (Fig. 14a) 


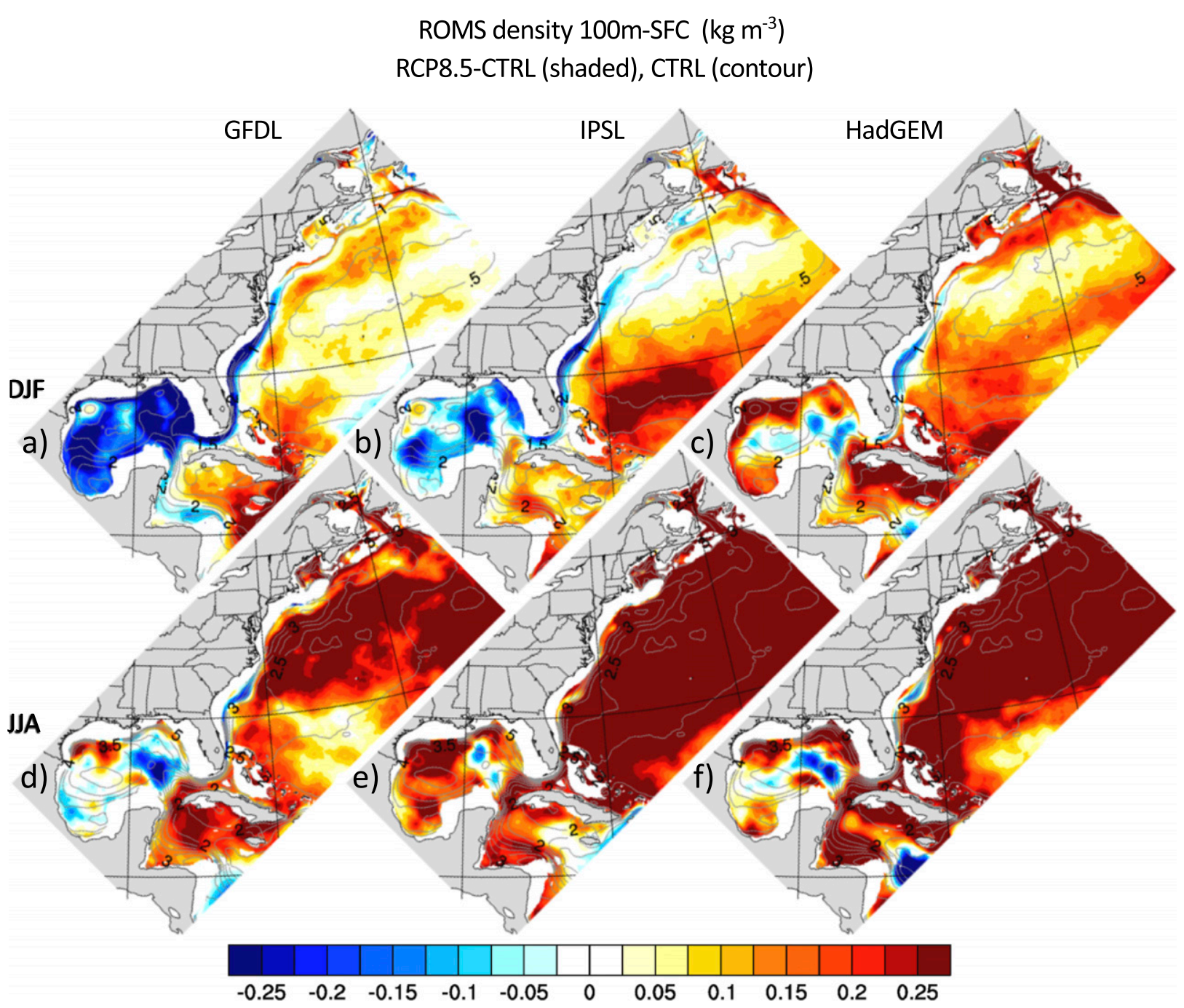

FIG. 10. Static stability, derived from the density difference between $100 \mathrm{~m}$ and the surface, in the CTRL (contours, interval of $0.25 \mathrm{~kg} \mathrm{~m}^{-3}$ ) and the static stability response (RCP8.5 - CTRL; shaded, interval of $0.025 \mathrm{~kg} \mathrm{~m}^{-3}$ ) in ROMS during (top) DJF and (bottom) JJA in (a),(d) GFDL-ROMS, (b),(e) IPSL-ROMS, and (c),(f) HadGEM-ROMS.

indicating a southward displacement of the current where the Gulf Stream is mainly zonal. The responses in IPSL-ROMS and HadGEM-ROMS exhibit an anomalous anticyclonic (clockwise) gyre starting near Cape Hatteras, where the current separates from the coast, to the south of Long Island $\left(\sim 72^{\circ} \mathrm{W}\right.$; Fig. $\left.13 \mathrm{c}\right)$ in IPSL-ROMS and Cape Cod $\left(\sim 65^{\circ} \mathrm{W}\right.$; Fig. 13d) in HadGEM-ROMS. This feature weakens the northern core of the Gulf Stream but enhances northeasterly flows along its northern edge (Figs. 11 and 13). The latter aspect of the response is consistent with Saba et al. (2016), who found enhanced meridional flow nearshore $\left(\sim 36^{\circ} \mathrm{N}, 74^{\circ} \mathrm{W}\right)$ and a northward shift of the current. However, the enhanced flow on the northernmost edge of the Gulf Stream remains south of $\sim 40^{\circ} \mathrm{N}$ and west of the Gulf of Maine in both IPSL-ROMS and HadGEM-ROMS (Figs. 11, 13 and 14). In addition, the response in all three ROMS simulations indicates that water enters the Gulf of Maine from the east along the Scotian Shelf and then flows counterclockwise around the basin. This enhances the mean circulation at the surface (Fig. 13) and at depths down to $200 \mathrm{~m}$ (as can be seen at https://www.esrl.noaa.gov/psd/ipcc/roms/roms.html). Thus, the responses of all three ROMS simulations, especially GFDL-ROMS, differ from the findings of Saba et al. (2016), who found that the warming in the Gulf of Maine at depth was due to a northward shift of the Gulf Stream. There are several potential explanations for why the Gulf of Maine warms without a northward shift in the Gulf Stream, as discussed in section 4.

The Gulf Stream is driven by both buoyancy and wind forcing over the North Atlantic, thus changes in its strength and position can be associated with AMOC and 


\section{ROMS SFC Currents $\left(\mathrm{cm} \mathrm{s}^{-1}\right)$ RCP8.5-CTRL}

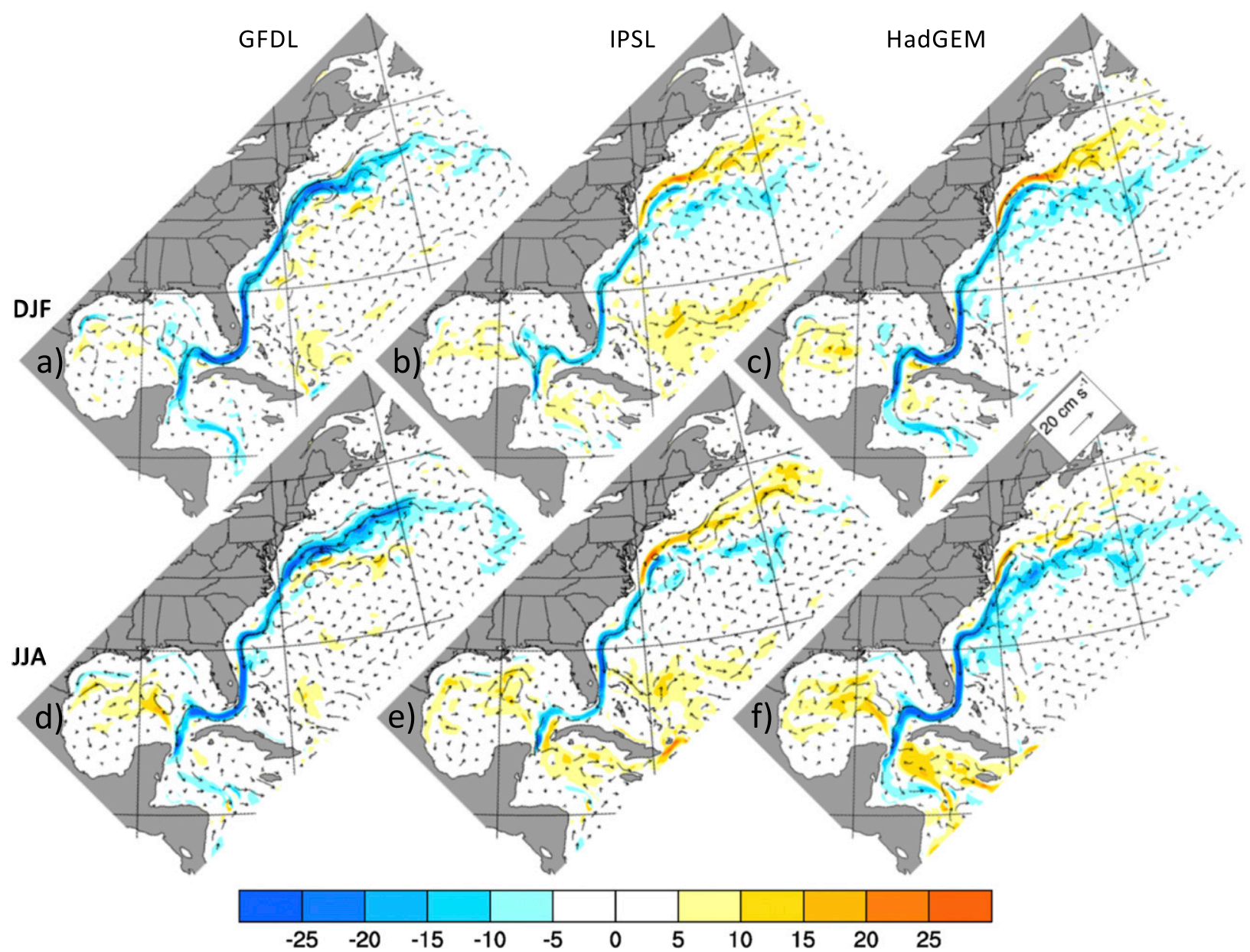

FIG. 11. Surface current response [RCP8.5 - CTRL; speed is shown by shading, interval of $5.0 \mathrm{~cm} \mathrm{~s}^{-1}$; vector scale is shown in (f)] in ROMS during (top) DJF and (bottom) JJA in (a),(d) GFDL-ROMS, (b),(e) IPSL-ROMS, and (c),(f) HadGEM-ROMs.

the wind driven gyre circulation. The latter is classically related to the zonal integration of the wind stress curl across the basin. The result that the surface winds (and thus zonally integrated wind stress curl) are very different in the three GCMs over the Atlantic Ocean (online supplemental Fig. SM12) suggests that it is changes in AMOC, rather than wind-driven changes in the gyre circulation, that are critical for the weakening of the Gulf Stream that is prevalent in all of the GCM and ROMS simulations. Changes in the basinwide wind stress, however, may contribute to the positional differences in the Gulf Stream among the three simulations. Regional changes in the buoyancy forcing, via surface fluxes of heat and freshwater, that result in changes in the gradients of density/sea surface height can also influence western boundary currents (Lowe and Gregory 2006; Suzuki and Ishii 2011; Liu et al. 2015).

\section{f. Eddies}

Eddy activity is represented by the eddy kinetic energy [EKE; $\left.0.5\left(u^{\prime 2}+v^{\prime 2}\right)\right]$, calculated from the currents in the surface layer, where the departures (primes) are obtained from pentad values after subtracting a 120-day mean centered on that pentad. In the CTRL, eddies are prominent in the Gulf Stream after it separates from the coast, in the Loop Current region of the Gulf of Mexico, and southeast of the Yucatan Peninsula in summer (contours in Fig. 15). The general pattern of the change in eddies in all three simulations is similar to those of the currents, with a decrease in eddy activity in the center of the Gulf Stream region, where the maximum EKE occurs in the CTRL. In GFDL-ROMS there is a decrease in EKE on the northern flank of the Gulf Stream and a slight decrease on its southern edge, and these changes 
ROMS $\left(30^{\circ} \mathrm{N}\right) \mathrm{X}$-section Annual Mean

RCP8.5-CTRL (shaded), CTRL (contour)

Ocean Meridional Velocity $\left(\mathrm{cm} \mathrm{s}^{-1}\right)$
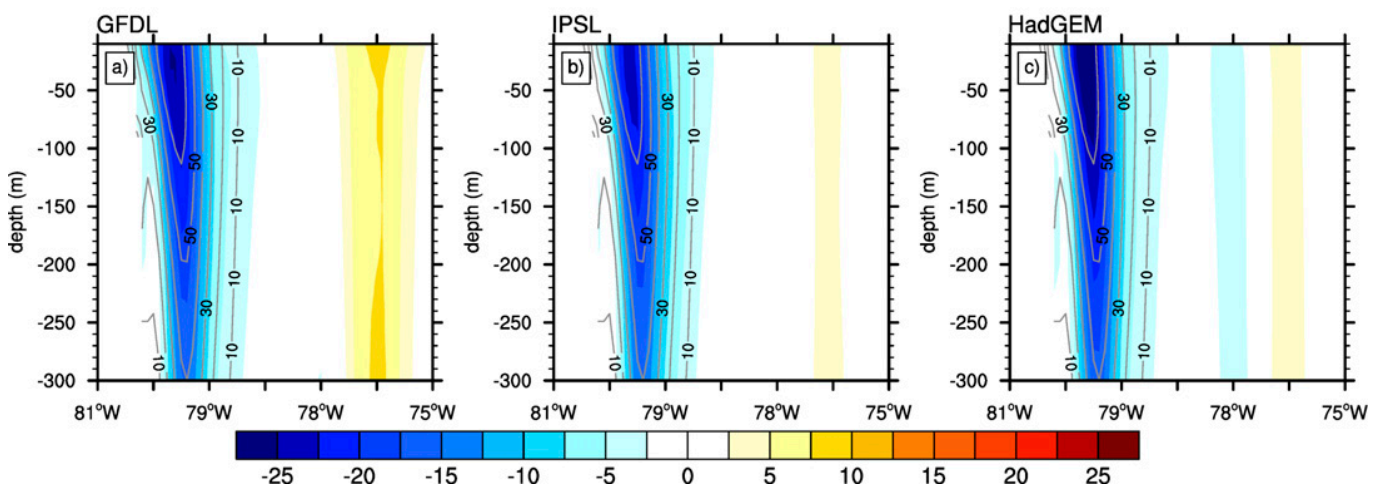

FIG. 12. Cross section of the annual mean meridional velocity along $30^{\circ} \mathrm{N}$ in the western North Atlantic (see Fig. 1) in ROMS. Shown are the velocity from the CTRL (contours, interval of $10 \mathrm{~cm} \mathrm{~s}^{-1}$ ) and the response (RCP8.5 - CTRL; shading, interval of $2.5 \mathrm{~cm} \mathrm{~s}^{-1}$ ) in (a),(d) GFDL-ROMS, (b),(e) IPSL-ROMS, and (c),(f) HadGEM-ROMS

are slightly larger in JJA then in DJF. In contrast, in IPSL-ROMS and HadGEM-ROMS there is an increase (decrease) in EKE on the northern (southern) edge of the Gulf Stream in both DJF and JJA. This increase in
EKE occurs in a narrow band from the coast northeastward for $\sim 8^{\circ}$ of longitude, but then becomes broader but more diffuse south of Nova Scotia $\left(\sim 65^{\circ} \mathrm{W}\right)$ and farther to the east. All three downscaled simulations show a decrease

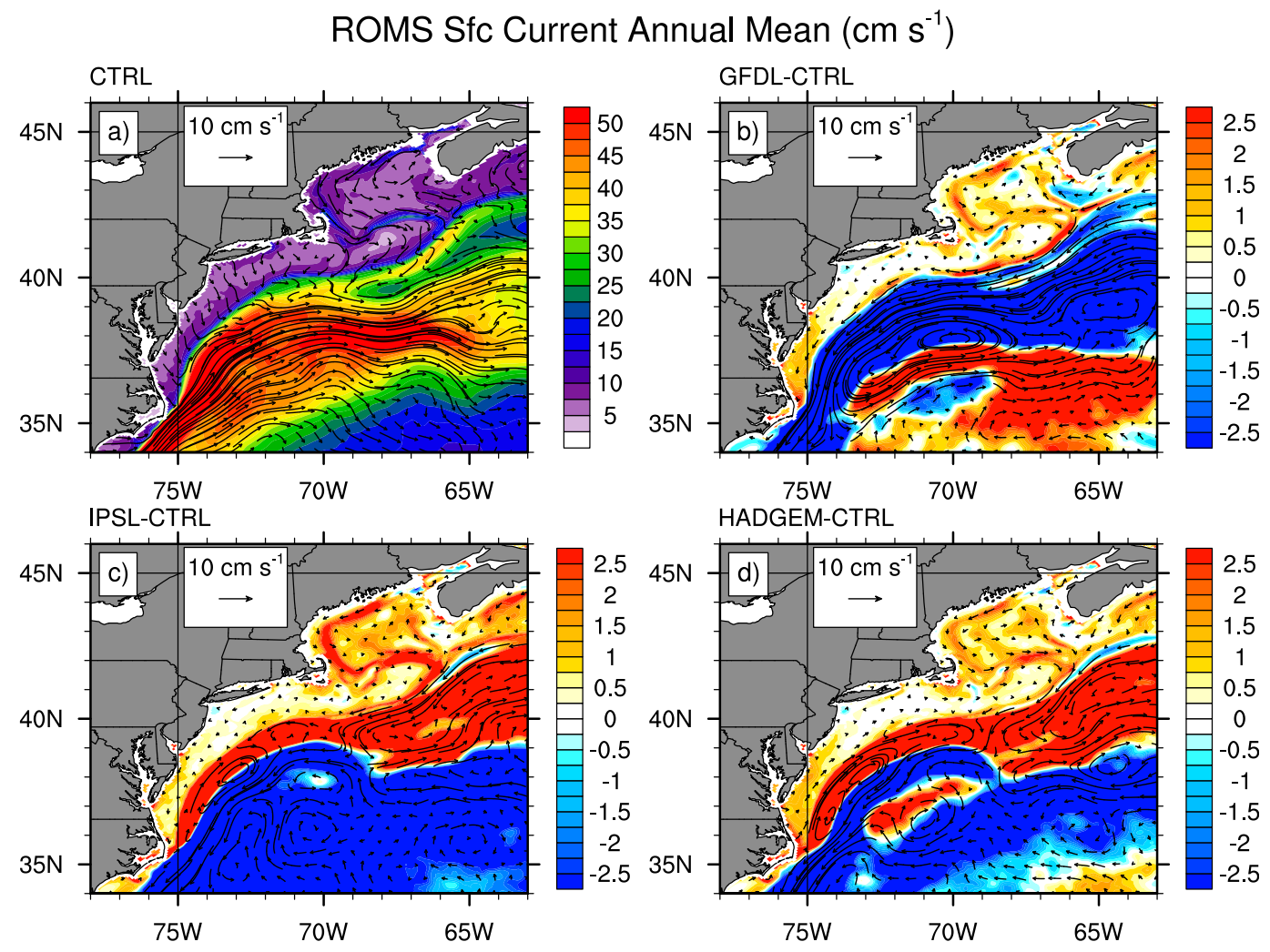

FIG. 13. Annual mean surface current off the U.S. northeast coast in the (a) CTRL $\left(2.5 \mathrm{~cm} \mathrm{~s}^{-1}\right.$ shading interval), and the current response (RCP8.5 - CTRL; shaded, interval of $0.25 \mathrm{~cm} \mathrm{~s}^{-1}$ ) in (b) GFDL-ROMS, (c) IPSL-ROMS and (d) HadGEM-ROMS. 
ROMS (70 W) X-section Annual Mean

RCP8.5-CTRL (shaded), CTRL (contour)

ROMS Ocean Zonal Velocity $\left(\mathrm{cm} \mathrm{s}^{-1}\right)$

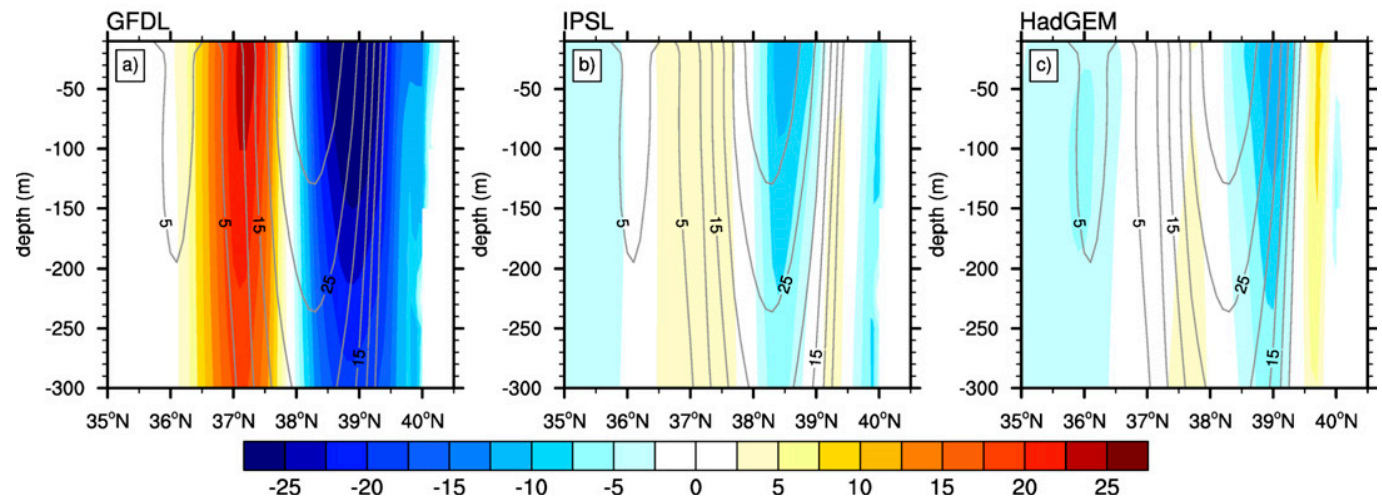

FIG. 14. Cross section of the annual mean meridional velocity along $70^{\circ} \mathrm{W}$ in the western North Atlantic (see Fig. 1) in ROMS. Shown are the velocity from the CTRL (contours, interval of $5 \mathrm{~cm} \mathrm{~s}^{-1}$ ) and the response (RCP8.5 - CTRL; shading, interval of $2.5 \mathrm{~cm} \mathrm{~s}^{-1}$ ) in (a) GFDL-ROMS, (b) IPSL-ROMS, and (c) HadGEM-ROMS.

in eddy activity in the vicinity of the Loop Current in DJF, with an increase (decrease) on its western (eastern) side during JJA. The EKE increases in the western half of the Gulf of Mexico (west of $90^{\circ} \mathrm{W}$ ) especially during summer. Farther south, the EKE differs between the simulations in the Caribbean Sea, where it generally decreases in the GFDL-ROMS in winter and on the western side of the sea in summer but increases in the IPSL-ROMS and HadGEM-ROMS in both seasons.

\section{Summary and conclusions}

We used the regional ocean model system (ROMS) with 7-km resolution to downscale the effects of climate change on the western North Atlantic and Gulf of Mexico. First, a control simulation (CTRL) was conducted using observationally based atmosphere and ocean fields as boundary conditions. Then monthly mean differences $(\Delta s)$ in surface fluxes and ocean conditions between the periods of 1976-2005 and 2070-99 were obtained from three CMIP5 GCMs: GFDL, IPSL, and HadGEM, and added to the CTRL. Last, the response to anthropogenic forcing was obtained from the difference between each of the three $\Delta$-forced simulations and the CTRL.

The climate change response in the three downscaled simulations, termed GFDL-ROMS, IPSL-ROMS, and HadGEM-ROMS, during winter (DJF) and summer (JJA) reflects both the large-scale forcing and more regional changes resulting from mesoscale dynamics and interaction with coastal features. All three simulations show strong increases in SSTs over most of the domain, except in the vicinity of the U.S. mid-Atlantic coast during DJF, where weaker warming is associated with a reduction in strength of the Gulf Stream. Eddies also effect temperatures in the western North Atlantic (Griffies et al. 2015; Saenko 2015; Treguier et al. 2017) and likely influence the SST changes that occur in our experiments. The difference in the SST response between the Gulf Stream and the surrounding ocean decreases in summer as a shallow mixed layer forms and the heating from the atmosphere is distributed over a thinner layer.

Consistent with previous studies, the weakening of the Gulf Stream is likely caused by a reduction in highlatitude buoyancy and a slowing of AMOC, as opposed to wind-driven changes in the gyre circulations, since the wind stress changes across the Atlantic are very different in the three GCMs used to drive ROMS. Regional differences in surface fluxes, which alter the gradients of density of the upper ocean may also influence western boundary currents (Lowe and Gregory 2006; Suzuki and Ishii 2011; Liu et al. 2015).

The large-scale forcing can also result in substantial differences among the three ROMS simulations. The warming of SSTs north of the Gulf Stream increases in magnitude and extent from GFDL-ROMS to IPSL-ROMS to HadGEM-ROMS, with the response in HadGEM-ROMS being approximately $1^{\circ}-2.5^{\circ} \mathrm{C}$ stronger than in GFDL north of $\sim 40^{\circ} \mathrm{N}$. While the warming in HadGEM-ROMS tends to be largest at or near the surface, the maximum warming is often at depth in GFDL-ROMS.

The large-scale differences in the temperature and salinity response as a function of depth strongly influences the changes in nearshore regions, which are well resolved in the ROMS simulations but not in the GCMs. For example, the strongest warming in GFDL-ROMS enters the Gulf of Saint Lawrence and Gulf of Maine 


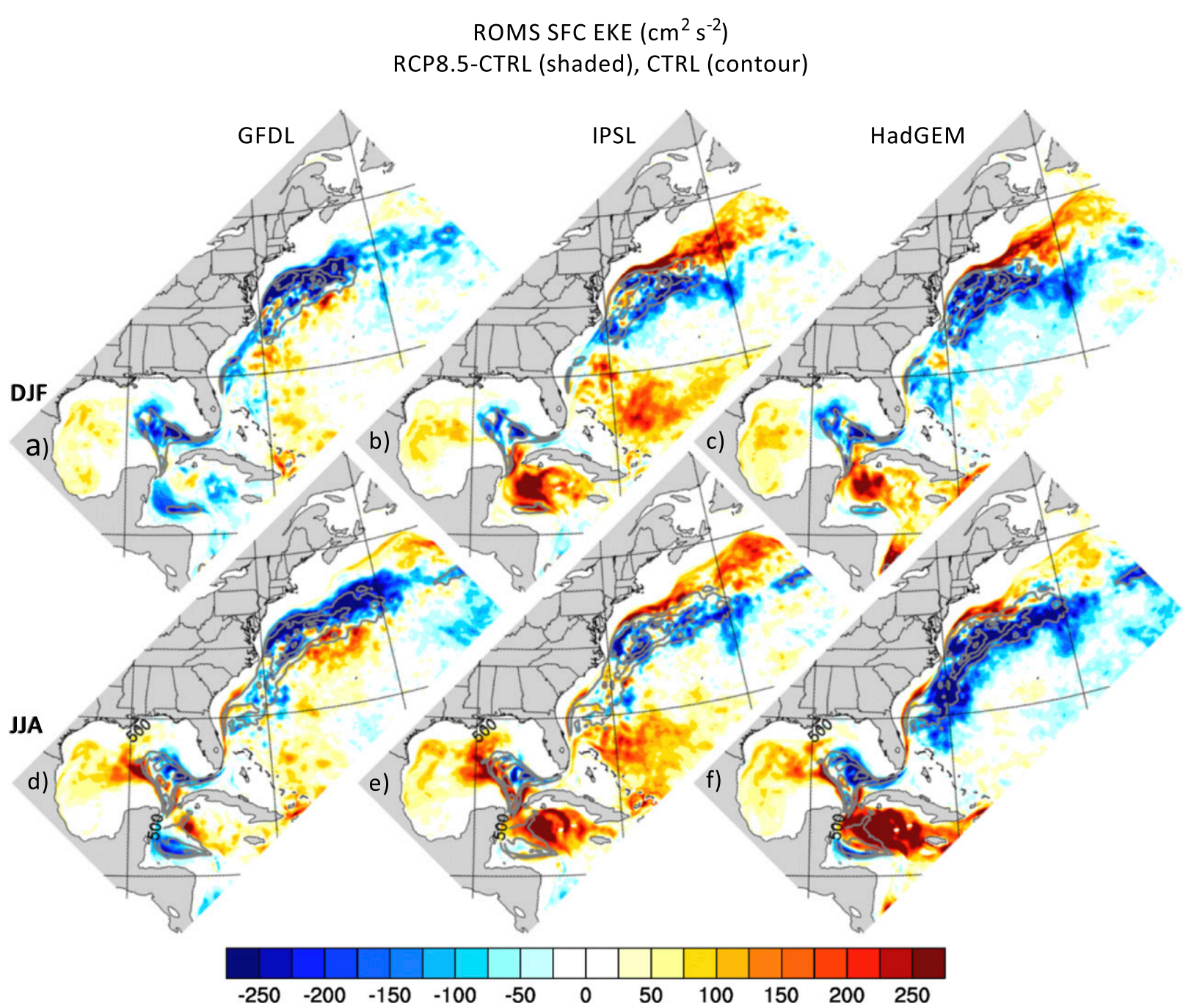

FIG. 15. Surface EKE in the CTRL (contours, interval of $250 \mathrm{~cm}^{2} \mathrm{~s}^{-2}$ starting at 500) and the EKE response (RCP8.5 - CTRL; shaded, interval of $25 \mathrm{~cm}^{2} \mathrm{~s}^{-2}$ ) in ROMS during (top) DJF and (bottom) JJA in (a),(d) GFDL-ROMS, (b), (e) IPSL-ROMS, and (c),(f) HadGEMROMS. The EKE is computed by removing the 120-day running mean from the 5-day average velocity.

near the bottom of deep channels, while the maximum warming occurs higher in the water column in the other two simulations resulting in greater warming along the banks of these two gulfs. The vertical structure of the salinity response is also markedly different in the three downscaled simulations in some regions. For example, the salinity decreases in the surface layer in the Gulf of Maine and increases at depth in GFDLROMS simulation, while the salinity increase extends over the depth of the Gulf of Maine in the other two simulations.

Differences in the downscaled simulations also arise in the Gulf of Mexico, where the largest increase in temperature occurs within the thermocline during winter in GFDL-ROMS and to a lesser degree in IPSLROMS but occurs near the surface in HadGEM-ROMS.
As a result, the stratification, as given by the difference in density between the surface and $100 \mathrm{~m}$, actually decreases over the most of the Gulf of Mexico in GFDLROMS and IPSL-ROMS in winter, opposite to the general increase in stratification that is projected to occur over most of the world's oceans. The response is especially strong where thermocline abuts the shelf, creating exceptionally warm $\left(>4^{\circ} \mathrm{C}\right)$ bottom temperatures on the west Florida slope and West Florida Shelf. Other processes also influence the response in the Gulf of Mexico. For example, changes in runoff from the Mississippi River, which greatly increases in HadGEMROMS, results in a decrease in salinity in the northern gulf. In addition, enhanced eddy activity occurs on the western side of the Loop Current and extends across the western portion of the basin in all three downscaled 
simulations, suggesting that more eddies may shed from the Loop Current and propagate westward in the future. Thus, a wide array of both atmosphere and ocean processes may influence how climate change unfolds in the Gulf of Mexico.

In addition to the overall reduction in the strength of the western boundary current system, including the Yucatan, Loop, and Florida Currents as well as the Gulf Stream, the fine resolution in the ROMS simulations allows for regional ocean circulation changes. The Gulf Stream exhibits a southward shift in GFDL-ROMS and a slight northward shift in the other two ROMS simulations. The northward shift is part of an elongated anticyclonic gyre circulation that reaches approximately $72^{\circ}$ and $65^{\circ} \mathrm{W}$ in the IPSL-ROMS and HadGEM-ROMS, respectively. A commensurate meridional shift occurs in the eddy kinetic energy. However, all three model simulations suggest that the changes in the Gulf Stream remain well to the south of New England and that climate change enhances the present-day circulation, with water entering the Gulf of Maine from the east and then flowing counterclockwise around the basin (also see Shin and Alexander 2020). In contrast, using a high-resolution global model, Saba et al. (2016) found that enhanced warming at depth in the Gulf of Maine was due to a northward shift of the Gulf Stream.

Since a northward shift of the Gulf Stream does not appear to directly cause the enhanced warming in the Gulf of Maine, what processes could be involved in the very strong temperature response there? The enhanced warming in the Gulf of Maine and Gulf of Saint Lawrence may result from a number of processes, including the following:

- Very strong warming of the atmosphere over eastern Canada $\left(>8^{\circ} \mathrm{C}\right)$ that is transported over the Atlantic due to advection by westerly winds (see Fig. 3), heating the ocean via changes in the surface fluxes. This atmospheric-related heating may partly explain the warming adjacent to the northeast United States and Atlantic Canadian provinces as indicated by presentday ocean heat budget analyses (Chen et al. 2015, 2016) and by climate equilibrium studies in which greenhouse gases are increased (often doubled) in a global atmospheric model that is coupled to an ocean model without currents (e.g., Danabasoglu and Gent 2009; Dommenget 2012). The increase in surface air temperatures over North America is modest, intermediate, and strong in the GFDL, IPSL, and HadGEM models, respectively, which corresponds to the magnitude of the warming of SSTs off the coast of New England and Canada's Atlantic provinces in both the GCMs and the corresponding ROMS simulations.
- With polar amplification of the climate change signal, the Arctic Ocean and Labrador Sea are projected to undergo very strong warming by the end of the twenty-first century, especially in regions where the ice has retreated from. This much warmer water relative to today's climate can then be advected by the East Greenland and Labrador Currents from Newfoundland to the northeast U.S. coast.

- The reduction in AMOC enhances the absorption of heat from the atmosphere at high latitudes (Rugenstein et al. 2013), which can subsequently be advected by the Labrador Current to the northeast U.S. shelf as described above.

- CMIP5 models, including the three used here, indicate a small region of very strong warming in the vicinity of $\sim 44^{\circ} \mathrm{N}-45^{\circ} \mathrm{W}$, southeast of Newfoundland, associated with more northward directed currents in the future (online supplemental Fig. SM13). While most of the changes in currents are directed toward the southwest, these changes in temperature and currents appear to be linked to the overall reduction in AMOC (Cheng et al. 2013; Winton et al. 2013; Buckley and Marshall 2016). The very warm water can subsequently be advected into the Gulf of Maine as indicated by backward trajectories derived from the GFDL-ROMS simulation (Shin and Alexander 2020) and analyses of observations and a model simulation of the past decade (Brickman et al. 2018).

- Ocean eddies in the vicinity of the Gulf Stream may transport warm salty water toward the northeast U.S. shelf, especially in the IPSL-ROMS and HadGEMROMS simulations, where there are semipermanent eddies south of Nova Scotia (Fig. 13) and an increase in transient eddy activity on the northern flank of the Gulf Stream/North Atlantic Current (Fig. 15).

Differences in salinity also occur along the northeast U.S. coast among the three ROMS simulations and between the global and downscaled simulations. The southward extent of enhanced freshening is greatest in GFDL-ROMS, where it extends to Cape Hatteras off North Carolina at both the surface and on the bottom, while it is primarily confined to Canadian waters in IPSL-ROMS and HadGEM-ROMS during DJF (Figs. 5 and 6). In addition, the freshening along the northeast coast extends farther south in GFDL-ROMS than in the corresponding GCM simulation. The salinity response may reflect changes in salinity advection due both to changes in the currents and changes in the water properties (i.e., the water becoming fresher). The southward shift in the Gulf Stream, which only occurs in the GFDL-ROMS simulation, enables currents to transport relatively freshwater originating in the Labrador Sea/Subarctic Gyre all the way 
ROMS $\Delta$ Salinity (PSU), $\Delta$ Zonal Veloctiy $(\mathrm{cm} / \mathrm{s})$ at $70.0^{\circ} \mathrm{W}$ DJF
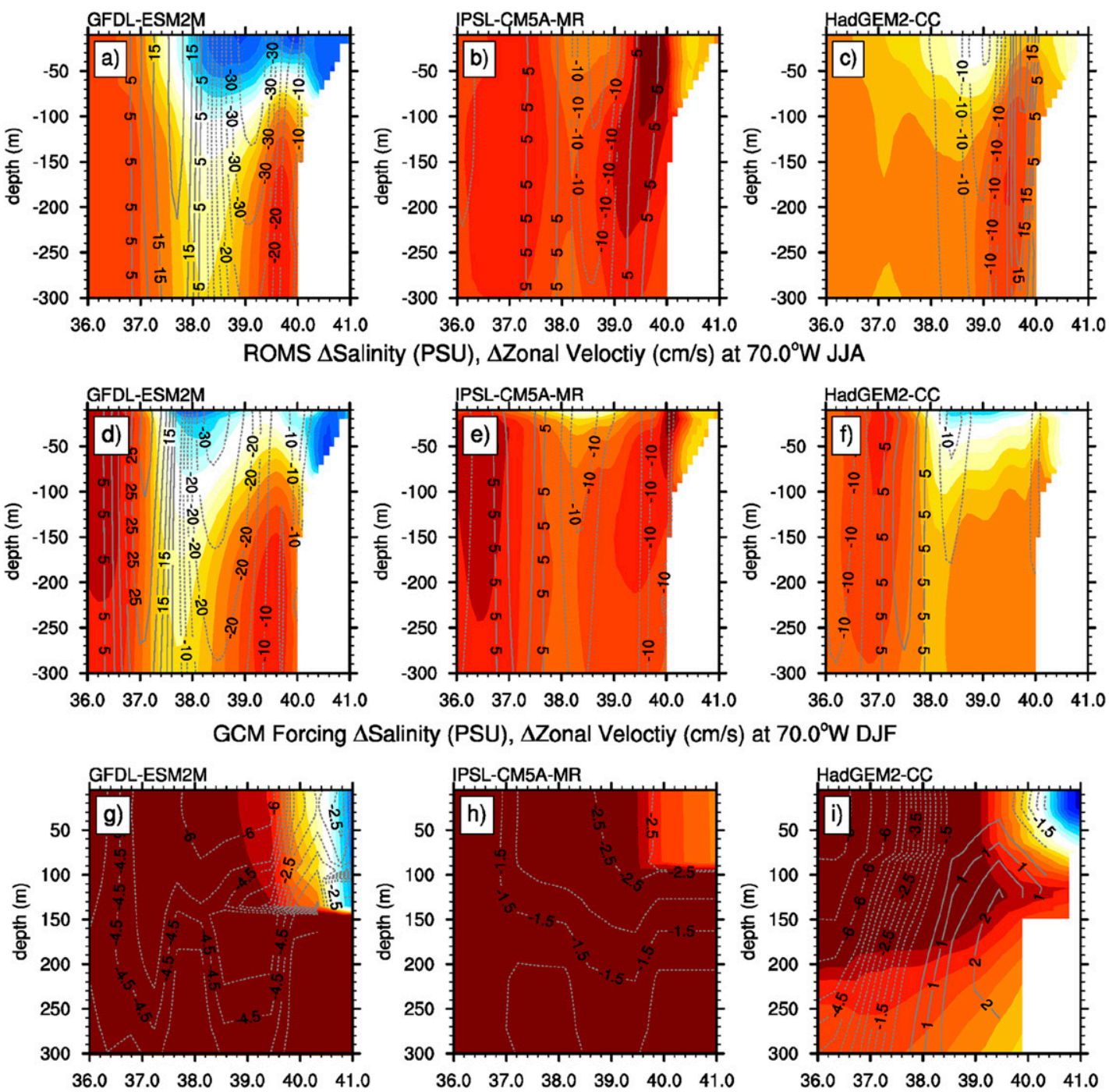

GCM Forcing $\Delta$ Salinity (PSU), $\Delta$ Zonal Veloctiy $(\mathrm{cm} / \mathrm{s})$ at $70.0^{\circ} \mathrm{W} J J A$

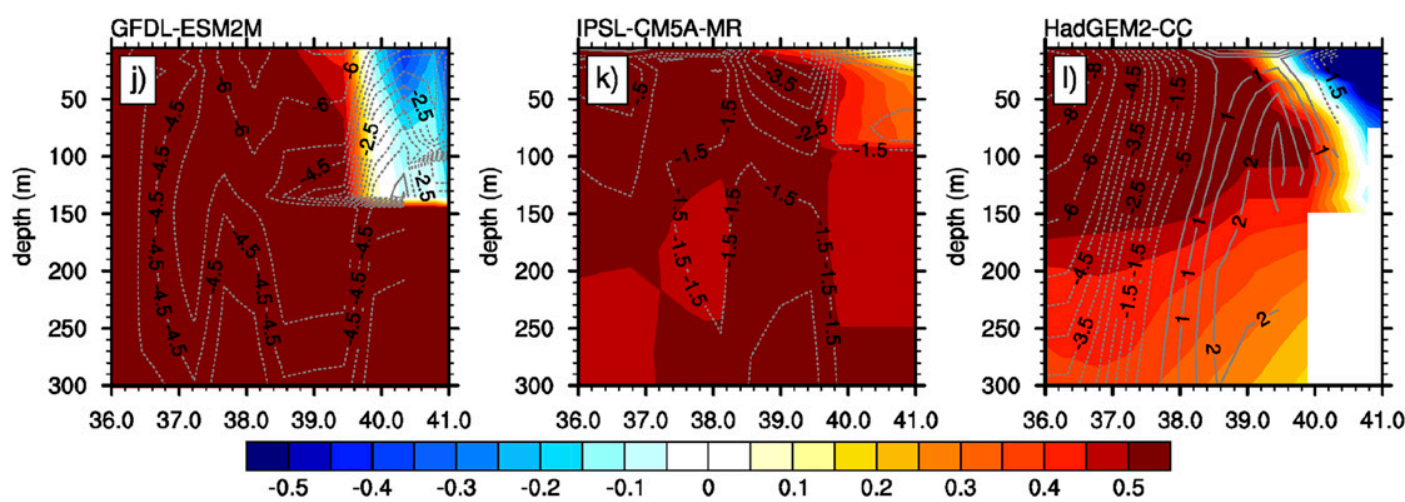

FIG. 16. Cross section along $70^{\circ} \mathrm{W}$ of the response of zonal currents (contours, negative values are easterly) and salinity (shaded, interval of 0.05 PSU) to climate change forcing in the three ROMS simulations during (a)-(c) DJF and (d)-(f) JJA and for the corresponding GCM simulations during (g)-(i) DJF and (j)-(l) JJA. Note that the contour interval is $10 \mathrm{~cm} \mathrm{~s}^{-1}$ for ROMS and $0.5 \mathrm{~cm} \mathrm{~s}^{-1}$ for the GCMs. 
to where the Gulf Stream separates from the coast at Cape Hatteras. In addition, the large-scale forcing causes strong freshening in the northeast part of the domain, especially in the GFDL and HadGEM models. The decrease in salinity is maintained in an upper layer adjacent to the northeast coast in the GFDL-ROMS off the New England coast (Fig. 8). A cross section of the zonal current and the salinity response along $70^{\circ} \mathrm{W}$ in the three ROMS simulations, highlights both the stronger westward (negative) current change and the enhanced freshening in the GFDL-ROMS model relative to the other two downscaled simulations (Fig. 16). In contrast, the response exhibits a narrow band of eastward currents and increased salinity in the vicinity of $39.7^{\circ} \mathrm{N}$, suggesting eastward salinity advection south of Cape Cod in the IPSL-ROMS and HadGEM-ROMS simulations. While freshening also occurs off the New England coast in the GFDL GCM (Fig. SM4), the current changes are much weaker and the change in salinity confined closer to the coast than in the corresponding ROMS integrations (Fig. 16). Thus, the surface-layer freshening can be maintained and advected southeastward by stronger coastal currents in the GFDL-ROMS simulation relative to the more diffusive and sluggish GFDL GCM. In addition, the freshwater flux at the surface increases $(\Delta \mathrm{E}-\mathrm{P}<0)$ as a result of climate change just off the east coast of the mid-Atlantic states in summer in the GFDL and HadGEM GCMs (Fig. SM5), which contributes to the freshening that occurs in JJA in the corresponding ROMS simulations (Fig. 5). Other processes, such as river runoff, stratification, and eddy mixing, could also influence the detailed structure of the salinity changes.

While there is a strong link between changes in mean currents and eddy activity, for example, as illustrated by the corresponding meridional shift in the Gulf Stream and EKE in each ROMS integration, there is not necessarily a one-to-one relationship between them. For example, the Yucatan Current weakens while the EKE increases in the northwestern Caribbean Sea during DJF in HadGEM-ROMS (cf. Fig. 11c and Fig. 15c). Eddies are generated and dissipated by a wide range of processes, including interactions with mean currents and topography; wind and buoyancy forcing; and baroclinic, barotropic, and symmetric instabilities (e.g., McWilliams 2008). These processes vary with the seasonal cycle and location, including in the Gulf Stream region (e.g., Kang and Curchitser 2015; Kang et al. 2016) and the Gulf of Mexico (Oey et al. 2005), where eddy activity can be strong during summer. Anticyclonic eddies are generated in the Loop Current and propagate westward across the Gulf of Mexico, where eddy shedding preferentially occurs in summer and winter relative to spring and fall (Chang and Oey 2012; Hall and Leben 2016). In our three experiments, the EKE is strongly enhanced on the western and northern flanks of the Loop Current in summer but not in winter and the increase in EKE is somewhat stronger in JJA than DJF across the western portion of the Gulf of Mexico. One potential source of these differences may lie in the seasonal change in the winds over the Caribbean Sea and Gulf of Mexico (Fig. SM12), which influence the northward extent of the Loop Current and eddy shedding (Chang and Oey 2012). The links between the changes in winds, AMOC/ western boundary currents, and eddies are multifaceted and thus warrant further study.

The differences between the three ROMS simulations, and between the ROMS simulations and the highresolution global model simulation analyzed by Saba et al. (2016), indicate that while high resolution allows for better representation of the large-scale and regional circulation, it does not guarantee the same climate change response, which depends on a wide range of factors. These findings suggest that even when using dynamically downscaled regional ocean models or highresolution global models to investigate the oceanic response to climate change, one should use an ensemble of global models with multiple realizations from each model to capture structural uncertainty in the models and the range of potential outcomes that result.

Acknowledgments. We thank Michael Jacox, the three anonymous reviewers, and Oleg Saenko-the editor-for their constructive comments. This study is supported by grants from the NOAA Coastal and Climate Applications (COCA) program NA-15OAR4310133 and NA-17OAR4310268. Contributing support for this work was provided by the NOAA Integrated Ecosystem Assessment (IEA) Program. This paper is IEA Contribution Number 2019_7.

\section{REFERENCES}

Alexander, M. A., J. D. Scott, K. D. Friedland, K. E. Mills, J. A. Nye, A. J. Pershing, and A. C. Thomas, 2018: Projected sea surface temperatures over the 21st century: Changes in the mean, variability and extremes for large marine ecosystem regions of Northern Oceans. Elem. Sci. Anthropocene, 6, 9 , https://doi.org/10.1525/elementa.191.

Auad, G. A., E. Miller, and E. Di Lorenzo, 2006: Long-term forecast of oceanic conditions off California and their biological implications. J. Geophys. Res., 111, C09008, https:// doi.org/10.1029/2005JC003219.

Belkin, I. M., 2009: Rapid warming of large marine ecosystems. Prog. Oceanogr., 81, 207-213, https://doi.org/10.1016/j.pocean. 2009.04.011.

Boyer, T. P., S. Levitus, J. I. Antonov, R. A. Locarnini, and H. E. Garcia, 2005: Linear trends in salinity for the World Ocean, 1955-1998. Geophys. Res. Lett., 32, L01604, https://doi.org/ 10.1029/2004GL021791. 
Brickman, D., D. Hebert, and Z. Wang, 2018: Mechanism for the recent ocean warming events on the Scotian Shelf of eastern Canada. Cont. Shelf Res., 156, 11-24, https://doi.org/10.1016/ j.csr.2018.01.001.

Bryan, F. O., M. W. Hecht, and R. D. Smith, 2007: Resolution convergence and sensitivity studies with North Atlantic circulation models. Part I: The western boundary current system. Ocean Modell., 16, 141-159, https://doi.org/10.1016/ j.ocemod.2006.08.005.

Buckley, M. W., and J. Marshall, 2016: Observations, inferences, and mechanisms of Atlantic meridional overturning circulation variability: A review. Rev. Geophys., 54, 5-63, https:// doi.org/10.1002/2015RG000493.

Caesar, L., S. Rahmstorf, A. Robinson, G. Feulner, and V. Saba, 2018: Observed fingerprint of a weakening Atlantic Ocean overturning circulation. Nat. Climate Change, 556, 191-196, https://doi.org/10.1038/s41586-018-0006-5.

Capotondi, A., M. A. Alexander, N. A. Bond, E. N. Curchitser, and J. D. Scott, 2012: Enhanced upper ocean stratification with climate change in the CMIP3 models. J. Geophys. Res., 117, C04031, https://doi.org/10.1029/2011JC007409.

Carton, J. A., and B. S. Giese, 2008: A reanalysis of ocean climate using Simple Ocean Data Assimilation (SODA). Mon. Wea. Rev., 136, 2999-3017, https://doi.org/10.1175/2007MWR1978.1.

Chang, Y.-L., and L.-Y. Oey, 2012: Why does the Loop Current tend to shed more eddies in summer and winter? J. Geophys. Res., 39, L05605, https://doi.org/10.1029/2011GL050773.

Chen, K., G. G. Gawarkiewicz, S. J. Lentz, and J. M. Bane, 2014: Diagnosing the warming of the Northeastern U.S. Coastal Ocean in 2012: A linkage between the atmospheric jet stream variability and ocean response. J. Geophys. Res. Oceans, $\mathbf{1 1 9}$, 218-227, https://doi.org/10.1002/2013JC009393.

- - - Y.-O. Kwon, and W. G. Zhang, 2015: Role of atmospheric forcing versus ocean advection during the anomalous warming on the northeast U.S. shelf in 2012. J. Geophys. Res., 120, 4324-4339, https://doi.org/10.1002/2014JC010547.

_ , Y.-O. Kwon, and G. Gawarkiewicz, 2016: Interannual variability of winter-spring temperature in the Middle Atlantic Bight: Relative contributions of atmospheric and oceanic processes. J. Geophys. Res. Oceans, 121, 4209-4227, https:// doi.org/10.1002/2016JC011646.

Chen, Z., E. Curchitser, R. Chant, and D. Kang, 2018: Seasonal variability of the cold pool over the Mid-Atlantic Bight continental shelf. J. Geophys. Res. Oceans, 123, 8203-8226, https:// doi.org/10.1029/2018JC014148.

Cheng, W., J. C. Chiang, and D. Zhang, 2013: Atlantic meridional overturning circulation (AMOC) in CMIP5 models: RCP and historical simulations. J. Climate, 26, 7187-7197, https:// doi.org/10.1175/JCLI-D-12-00496.1.

Collins, M., and Coauthor, 2013: Long-term climate change: Projections, commitments and irreversibility. Climate Change 2013: The Physical Science Basis, T. F. Stocker et al., Eds., Cambridge University Press, 1029-1136.

Coumou, D., G. Di Capua, S. Vavrus, L. Wang, and S. Wang, 2018: The influence of Arctic amplification on mid-latitude summer circulation. Nat. Commun., 9, 2959, https://doi.org/10.1038/ s41467-018-05256-8.

Dai, A., T. Qian, K. E. Trenberth, and J. D. Milliman, 2009: Changes in continental freshwater discharge from 1948 to 2004. J. Climate, 22, 2773-2792, https://doi.org/10.1175/ 2008JCLI2592.1.

Danabasoglu, G., 2008: On multidecadal variability of the Atlantic meridional overturning circulation in the Community Climate
System Model version 3. J. Climate, 21, 5524-5544, https:// doi.org/10.1175/2008JCLI2019.1.

- and P. R. Gent, 2009: Equilibrium climate sensitivity: Is it accurate to use a slab ocean model? J. Climate, 22, 2494-2499, https://doi.org/10.1175/2008JCLI2596.1.

Deser, C., A. S. Phillips, M. A. Alexander, and B. V. Smoliak, 2014: Projecting North American climate over the next 50 years: Uncertainty due to internal variability. J. Climate, 27, 22712296, https://doi.org/10.1175/JCLI-D-13-00451.1.

Dommenget, D., 2012: Comments on "The relationship between land-ocean surface temperature contrast and radiative forcing." J. Climate, 25, 3437-3440, https://doi.org/10.1175/ JCLI-D-11-00476.1.

Drijfhout, S., G. J. van Oldenborgh, and A. Cimatoribus, 2012: Is a decline of AMOC causing the warming hole above the North Atlantic in observed and modeled warming patterns? J. Climate, 25, 8373-8379, https://doi.org/10.1175/JCLI-D-1200490.1.

Flato, G., and Coauthors, 2013: Evaluation of climate models. Climate Change 2013: The Physical Science Basis, T. F. Stocker et al., Eds., Cambridge University Press, 741-866.

Gleckler, P. J., K. E. Taylor, and C. Doutriaux, 2008: Performance metrics for global climate models. J. Geophys. Res., 113, D06104, https://doi.org/10.1029/2007JD008972.

Gregory, J. M., and Coauthors, 2005: A model intercomparison of changes in the Atlantic thermohaline circulation in response to increasing atmospheric $\mathrm{CO}_{2}$ concentration. Geophys. Res. Lett., 32, L12703, https://doi.org/10.1029/2005GL023209.

Griffies, S. M., and Coauthors, 2015: Impacts on ocean heat from transient mesoscale eddies in a hierarchy of climate models. J. Climate, 28, 952-977, https://doi.org/10.1175/JCLI-D-1400353.1.

Hall, C. A., and R. R. Leben, 2016: Observational evidence of seasonality in the timing of loop current eddy separation. Dyn. Atmos. Oceans, 76, 240-267, https://doi.org/10.1016/ j.dynatmoce.2016.06.002.

Hare, J. A., and Coauthors, 2012: Cusk (Brosme brosme) and climate change: Assessing the threat to a candidate marine fish species under the U.S. Endangered Species Act. ICES J. Mar. Sci., 69, 1753-1768, https://doi.org/10.1093/icesjms/fss160.

Hermann, A. J., and Coauthors, 2016: Projected future biophysical states of the Bering Sea. Deep-Sea Res. II, 134, 30-47, https:// doi.org/10.1016/j.dsr2.2015.11.001.

Heuzé, C., 2017: North Atlantic deep water formation and AMOC in CMIP5 models. Ocean Sci., 13, 609-622, https://doi.org/ 10.5194/os-13-609-2017.

Jun, M., R. Knutti, and D. W. Nychka, 2008: Spatial analysis to quantify numerical model bias and dependence: How many climate models are there? J. Amer. Stat. Assoc., 103, 934-947, https://doi.org/10.1198/016214507000001265.

Kang, D., and E. N. Curchitser, 2013: Gulf Stream eddy characteristics in a high-resolution ocean model. J. Geophys. Res. Oceans, 118, 4474-4487, https://doi.org/10.1002/jgrc.20318.

$\longrightarrow$, and - 2015: Energetics of eddy-mean flow interactions in the Gulf Stream region. J. Phys. Oceanogr., 45, 1103-1120, https://doi.org/10.1175/JPO-D-14-0200.1.

$\longrightarrow,-$, and A. Rosati, 2016: Seasonal variability of the Gulf Stream kinetic energy. J. Phys. Oceanogr., 46, 1189-1207, https://doi.org/10.1175/JPO-D-15-0235.1.

Karspeck, A. R., and Coauthors, 2017: Comparison of the Atlantic meridional overturning circulation between 1960 and 2007 in six ocean reanalysis products. Climate Dyn., 49, 957, https:// doi.org/10.1007/s00382-015-2787-7. 
Knutson, T. R., F. Zeng, and A. T. Wittenberg, 2013: Multimodel assessment of regional surface temperature trends: CMIP3 and CMIP5 twentieth-century simulations. J. Climate, 26, 8709-8743, https://doi.org/10.1175/JCLI-D-12-00567.1.

Knutti, R., C. Baumberger, and G. H. Hadorn, 2019: Uncertainty quantification using multiple models-Prospects and challenges. Computer Simulation Validation, C. Beisbart and N. Saam, Eds., Simulation Foundations, Methods and Applications Series, Springer, 835-855, https://doi.org/10.1007/ 978-3-319-70766-2_34.

Large, W. G., and S. G. Yeager, 2009: The global climatology of an interannually varying air-sea flux data set. Climate Dyn., 33, 341-364, https://doi.org/10.1007/s00382-008-0441-3.

Lima, F. P., and D. S. Wethey, 2012: Three decades of highresolution coastal sea surface temperatures reveal more than warming. Nat. Commun., 3, 704, https://doi.org/10.1038/ ncomms1713.

Liu, Y., S.-K. Lee, B. A. Muhling, J. T. Lamkin, and D. B. Enfield, 2012: Significant reduction of the Loop Current in the 21st century and its impact on the Gulf of Mexico. J. Geophys. Res., 117, C05039, https://doi.org/10.1029/2012JB009290.

- — , D. B. Enfield, B. A. Muhling, J. T. Lamkin, F. E. Muller-Karger, and M. A. Roffer, 2015: Potential impact of climate change on the Intra-Americas Sea: Part-1. A dynamic downscaling of the CMIP5 model projections. J. Mar. Sys., 148, 56-69, https://doi.org/10.1016/j.jmarsys.2015.01.007.

Liu, Z.-J., S. Minobe, Y. N. Sasaki, and M. Terada, 2016: Dynamical downscaling of future sea level change in the western North Pacific using ROMS. J. Oceanogr., 72, 905-922, https:// doi.org/10.1007/s10872-016-0390-0.

Lowe, J. A., and J. M. Gregory, 2006: Understanding projections of sea level rise in a Hadley Centre coupled climate model. J. Geophys. Res., 111, C11014, https://doi.org/10.1029/ 2005JC003421.

McWilliams, J. C., 2008: The nature and consequences of oceanic eddies. Ocean Modeling in an Eddying Regime, Geophys. Monogr., Vol. 177, Amer. Geophys. Union, 5-15, https:// doi.org/10.1029/177GM03.

Oey, L.-Y., T. Ezer, and H.-C. Lee, 2005: Loop Current, rings and related circulation in the Gulf of Mexico: A review of numerical models and future challenges. Circulation in the Gulf of Mexico: Observations and Models, Geophys. Monogr., Vol. 161, Amer. Geophys. Union, 32-56, https://doi.org/10.1029/ $161 \mathrm{GM} 04$.

Overland, J. E., M. Wang, N. A. Bond, J. E. Walsh, V. M. Kattsov, and W. L. Chapman, 2011: Considerations in the selection of global climate models for regional climate projections: The Arctic as a case study. J. Climate, 24, 1583-1597, https:// doi.org/10.1175/2010JCLI3462.1.

Pauly, D., and D. Zeller, Eds., 2016: Global Atlas of Marine Fisheries: A Critical Appraisal of Catches and Ecosystem Impacts. Island Press, 486 pp.

Pedersen, R. A., I. Cvijanovic, P. L. Langen, and B. M. Vinther, 2016: The impact of regional Arctic Sea ice loss on atmospheric circulation and the NAO. J. Climate, 29, 889-902, https://doi.org/10.1175/JCLI-D-15-0315.1.

Pershing, A. J., and Coauthors, 2015: Slow adaptation in the face of rapid warming leads to the collapse of Atlantic cod in the Gulf of Maine. Science, 350, 809-812, https://doi.org/10.1126/science.aac9819.

Rugenstein, M. A., M. Winton, R. J. Stouffer, S. M. Griffies, and R. Hallberg, 2013: Northern high-latitude heat budget decomposition and transient warming. J. Climate, 26, 609-621, https://doi.org/10.1175/JCLI-D-11-00695.1.
Saba, V. S., and Coauthors, 2016: Enhanced warming of the northwest Atlantic Ocean under climate change. J. Geophys. Res. Oceans, 121, 118-132, https://doi.org/10.1002/2015JC011346.

Saenko, O. A., 2015: Strong eddy compensation for the Gulf Stream heat transport. Geophys. Res. Lett., 42, 10 739-10 744, https://doi.org/10.1002/2015GL066111.

Sanderson, B. M., R. Knutti, and P. Caldwell, 2015: Addressing interdependency in a multimodel ensemble by interpolation of model properties. J. Climate, 28, 5150-5170, https://doi.org/ 10.1175/JCLI-D-14-00361.1.

Shchepetkin, A. F., and J. C. McWilliams, 2003: A method for computing horizontal pressure-gradient force in an oceanic model with a nonaligned vertical coordinate. J. Geophys. Res., 108, 3090, https://doi.org/10.1029/2001JC001047.

— (ROMS): A split-explicit, free-surface, topography-followingcoordinate oceanic model. Ocean Modell., 9, 347-404, https:// doi.org/10.1016/j.ocemod.2004.08.002.

Shearman, R. K., and S. J. Lentz, 2010: Long-term sea surface temperature variability along the U.S. East Coast. J. Phys. Oceanogr., 40, 1004-1017, https://doi.org/10.1175/2009JPO4300.1.

Shin, S.-I., and M. A. Alexander, 2020: Dynamical downscaling of future hydrographic changes over the northwest Atlantic Ocean. J. Climate, https://doi.org/10.1175/JCLI-D-19-0483.1, in press.

Sun, C., M. Feng, R. J. Matear, M. A. Chamberlain, P. Craig, K. R Ridgway, and A. Schiller, 2012: Marine downscaling of a future climate scenario for Australian boundary currents. $J$. Climate, 25, 2947-2962, https://doi.org/10.1175/JCLI-D-1100159.1.

Sun, L., M. Alexander, and C. Deser, 2018: Evolution of the global coupled climate response to Arctic sea ice loss during 1990 2090 and its contribution to climate change. J. Climate, 31, 7823-7843, https://doi.org/10.1175/JCLI-D-18-0134.1.

Suzuki, T., and M. Ishii, 2011: Regional distribution of sea level changes resulting from enhanced greenhouse warming in the Model for Interdisciplinary Research on Climate version 3.2. Geophys. Res. Lett., 38, L02601, https://doi.org/10.1029/ 2010GL045693.

Treguier, A. M., C. Lique, J. Deshayes, and J. M. Molines, 2017: The North Atlantic eddy heat transport and its relation with the vertical tilting of the Gulf Stream axis. J. Phys. Oceanogr., 47, 1281-1289, https://doi.org/10.1175/JPO-D-16-0172.1.

van Hooidonk, R. V., J. A. Maynard, Y. Liu, and S.-K. Lee, 2015: Downscaled projections of Caribbean coral bleaching that can inform conservation planning. Global Change Biol., 21, 33893401, https://doi.org/10.1111/gcb.12901.

Winton, M., S. M. Griffies, B. L. Samuels, J. L. Sarmiento, and T. L. Frölicher, 2013: Connecting changing ocean circulation with changing climate. J. Climate, 26, 2268-2278, https://doi.org/ 10.1175/JCLI-D-12-00296.1.

—, W. G. Anderson, T. L. Delworth, S. M. Griffies, W. J. Hurlin, and A. Rosati, 2014: Has coarse ocean resolution biased simulations of transient climate sensitivity? Geophys. Res. Lett., 41, 8522-8529, https://doi.org/10.1002/2014GL061523.

Wu, L., and Coauthors, 2012: Enhanced warming over the global subtropical western boundary currents. Nat. Climate Change, 2, 161-166, https://doi.org/10.1038/nclimate1353.

Xiu, P., F. Chai, E. N. Curchitser, and F. S. Castruccio, 2018: Future changes in coastal upwelling ecosystems with global warming: The case of the California Current System. Sci. Rep., 8, 2866, https://doi.org/10.1038/s41598-018-21247-7. 